\title{
Dijitalleşme Çağında Aktivist Halkla İlişkiler: Uluslararası Literatür Üzerine Bir Analiz ${ }^{1}$
}

Başvuru Tarihi: 05.10.2021 Yayın Kabul Tarihi: 25.12 .2021 Yayınlanma Tarihi: 30.12 .2021

\author{
Emine Gülal Şahin ${ }^{23}$ \\ Ankara Üniversitesi, Iletişim Fakültesi, \\ Halkla ilişkiler ve Tanıtım Bölümü, Ankara \\ gulal@ankara.edu.tr
}

(iD) ORCID: 0000-0001-9210-6256

\section{Öz}

Günümüz dijitalleşme çağında, internet sayesinde aktivist grupların gerçekleştirdiği halkla ilişkiler faaliyetleri artmıştır. Aktivist gruplar internet sayesinde kolayca organize olabilmekte, düşük maliyetle daha çok kişiye ulaşabilmekte ve dünya çapında bir farkındalık oluşturabilmektedirler. Dijital medya aracılığıyla gerçekleştirilen aktivist halka ilişkiler konusunun ele alındığı bu çalışmada, Web of Science'ta taranan ve halkla ilişkiler uluslararası literatüründe önemli bir yere sahip olan Public Relations Review, Public Relations Inquiry, Journal of Public Relations Research dergileri incelenmiştir. Incelenen dergilerde 2000-2020 tarihleri arasında yayımlanmış ve aktivist halkla iliskkiler ve dijital medya konuları arasında bağ kuran makaleler belirlenip, yeni medyanın aktivist halkla ilişkiler üzerine etkisini ortaya koymak amacıyla sistematik inceleme yöntemiyle analiz edilmiştir. Bulgular, aktivist gruplar, STK'lar ve toplumsal hareket örgütlerinin internet sayesinde aktivist halkla ilişkiler faaliyetlerinin arttığını bununla birlikte kâr amacı güden kurumların aktivist halkla ilişkiler faaliyetlerini daha az uyguladığını göstermektedir. Postmodern halkla ilişkiler anlayışında belirtildiği gibi, kurumların ve halkla ilişkiler çalışanlarının da aktivist halkla ilişkiler uygulamalarına başvurması gerekmektedir.

Anahtar Kelimeler: Dijitalleşme, aktivist halkla ilişkiler, dijital medya, aktivizm, halkla ilişkiler.

\footnotetext{
1 Bu makale, 20-21 Mayıs 2021 tarihleri arasında düzenlenen 4.Uluslararası Kültürel Bilişim, İletişim ve Medya Çalışmaları Konferansı'nda sözlü bildiri olarak sunulan çalışmanın genişletilmiş halidir.

2 Bu çalışmanın yazarı TÜBiTAK 2211-A Genel Yurt İçi Doktora Programı kapsamında desteklenmektedir.

${ }^{3}$ Araştırma Görevlisi
} 


\title{
Activist Public Relations in the Age of Digitalization: An Analysis on International ${ }^{4}$
}

Application Date: 05.10.2021 Accepted Date: 25.12.2021 Publishing Date: 30.12 .2021

\author{
Emine Gülal Şahin ${ }^{56}$
}

Ankara University, Faculty of Communication,

Department of Public Relations and Advertising, Ankara

gulal@ankara.edu.tr

(iD) ORCID: 0000-0001-9210-6256

\begin{abstract}
In today's digitalization era, public relations activities of activist groups have increased through the internet. Activist groups can easily organize, reach more people at low cost and create a worldwide awareness through the internet. In this study, which deals with the issue of activist public relations through new media, Public Relations Review, Public Relations Inquiry, Journal of Public Relations Research, that are scanned in Web of Science and have an important place in the international literatüre of public relations, were examined. The articles published in these journals between 2000-2020 linking activist public relations and new media issues were determined and analyzed with a systematic review method in order to reveal the effect of new media on activist public relations. The findings show that activist groups, NGOs and social movement organizations have increased their activist public relations activities through the internet however profit-oriented institutions practice few activist public relations activities. As stated in the postmodern public relations view, institutions and public relations practitioners should apply activist public relations activities.
\end{abstract}

Keywords: Digitalization, activist public relations, digital media, activism, public relations.

\footnotetext{
${ }^{4}$ This article is an extended version of the study presented as an oral statement at the 4th International Conference on Cultural Informatics, Communication and Media Studies held between 20-21 May 2021.

5 The author of this study is supported by TUBITAK 2211-A General Domestic Doctorate Program.

${ }^{6}$ Research Assistant
} 


\section{Giriş}

Halkla ilişkiler disiplinine intiyaç her dönemde olmuştur. Fakat günümüz dijitalleşme ve teknoloji çağında halkla ilişkilere olan intiyaç artmıştır. 2000 yılından itibaren, internet tüm dünyadaki insanları ve kurumları birbirine bağlayarak, dünyayı küresel bir topluma dönüştürmüştür (Wakefield, 2007, s.138). Dünyada dijitalleşmenin artmasıyla halkla ilişkilerde de bir dönüşüm yaşanmaktadır. Halkla ilişkiler uzmanlarının faaliyetlerini, yeni medyaya göre dönüştürmesi hayati bir zorunluluk haline gelmiştir. Dijital medya halkla ilişkiler alanı için hedef kitleye ulaşmada, faaliyetlerini gerçekleştirmede birçok avantaj sağlamış olsa da aynı zamanda kurumlar için birçok riski de beraberinde getirmektedir. Olası bir krizin internet sayesinde küresel ölçekte bir krize dönüşmesi artık mümkün görünmektedir.

Internetin yükselişi ile aktivist gruplar ve sivil toplum kuruluşlarının gerçekleştirdikleri aktivist halkla ilişkiler faaliyetleri de küresel anlamda farkındalık yaratmaya başlamıştır. Dijitalleşmeden önce medyanın sahiplik ve gelir yapısı sebebiyle aktivist hareketlerin medyada yer bulmaları zor olmuştur. Dijitalleşmeyle, aktivist etkinliklerin mekânsal, maliyet, organizasyon anlamında kapsamı genişlemiş ve görünürlüğü artmıştır. Fakat günümüz dijitalleşme çağında internet, aktivist gruplara daha hızlı organize olabilme, düşük maliyetle daha çok kişiye ulaşabilme ve etkinlikleri hakkında dünya çapında bir farkındalık oluşturabilme imkânı sunar.

Aktivist gruplar, belirli bir sorun hakkında gerçekleştirdikleri aktivist halkla ilişkiler faaliyetlerinde yeni medyayı kullanarak daha etkili sonuçlar elde edebilme imkânına sahiptir. Özellikle toplumsal ve çevresel sorunlarda dijital mecraların kullanımı küresel bir farkındalık sağlayabilir. $\mathrm{Bu}$ durumun aktivist halkla ilişkiler etkinliklerin hedefi konumundaki kâr amacı güden kuruluşlarda krizlere yol açması muhtemeldir. Bu bağlamda, bir sorun ortaya çıktığında kâr amacı güden kuruluşların sorunu iyi yönetebilmesi ve bu gruplarla uzlaşmaya gitmesi gerekmektedir. Çünkü günümüz internet çağında küçük bir sorunun dakikalar içinde küresel bir krize dönüşebilmesi muhtemeldir. Bununla birlikte, günümüzde artık yalnızca kâr odaklı olmanın yeterli olmadığı görülmektedir; postmodern halkla ilişkiler anlayışında ifade edildiği gibi kâr amacı güden kurumların da aktivist halkla ilişkiler faaliyetlerini gerçekleştirmeleri önem atfetmektedir.

Bu çalışmada dijital medya aracılığıyla gerçekleştirilen aktivist halkla ilişkiler üzerine uluslararası literatür incelenmiştir. Bu bağlamda, halkla ilişkiler uluslararası literatürü açısından önemli yere sahip olan, 'halkla ilişkiler' adıyla Web of Science'ta taranmakta olan ve Scimagojr sayfasında iletişim ve benzeri kategorilerde Q1'de taranmakta olan Public Relations Review, Public Relations Inquiry, Journal of Public Relations Research dergilerinde 2000-2020 yılları arasında yayımlanan ve dijital medya ve aktivist halkla ilişkiler ile ilişki kuran 15 makale tespit edilip sistematik inceleme yöntemiyle incelenmiştir. Sistematik inceleme yöntemi, araştırma soruları çerçevesinde ilgili literatürün kapsamlı olarak incelenmesini sağladığı için tercih edilmiştir. Çalışmanın ele aldığı sorunsal, dijital medyanın alternatif medya olarak ortaya çıkmasının aktivist halkla ilişkiler çalışmalarına nasıl katkı sağladığıdır. Bu sorunsal etrafında çalışmanın amacı, dijital medyanın aktivist halkla ilişkiler üzerindeki etkisini, önemini uluslararası literatür üzerinden ortaya koymaktır. Bu bağlamda, bu çalışma sistematik inceleme yöntemini kullanarak uluslararası literatürde aktivist halkla ilişkiler ve dijital medya konusu üzerinde genel eğilimleri, 


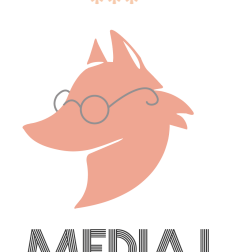

güncel çalışma alanlarını ortaya koymaktadır.

Yeni bir çalışma alanı olan dijital medya ve aktivist halkla ilişkiler üzerine Türkiye'de uluslararası literatürün uluslararası dergiler üzerinden incelendiği bir çalışma bulunmamaktadır. Bu bağlamda çalışmanın önemi, gelecekte yapılacak çalışmalara örnek teşkil etmesi açısından, yeni bir çalışma alanı olan ve sınırlı sayıda çalışmanın bulunduğu dijital medya ve aktivist halkla ilişkiler konusu hakkında yeni eğilim ve çalışma alanlarının üç uluslararası dergi üzerinden sistematik incelemesini sunmasıdır. Bu çalışmanın gelecek yıllarda farklı araştırmacılar tarafından aynı dergiler üzerinden tekrar edilmesi veya farklı uluslararası dergiler üzerinden ele alınması, karşılaştırma yapılması ve yeni yönelimlerin ortaya konması halkla ilişkiler alanına katkı sağlayacaktır.

\section{DiJiTAL HALKLA íLIŞKILER VE AKTIVIZM}

Halkla iliş̧kiler 20. yüzyılın başlarında sanayi ve teknolojik gelişmelerin bir uzantısı olarak Amerika'da ortaya çıkmış bir disiplindir. Genel olarak bakıldığında, halkla ilişkiler kavramı üzerine uzlaşılmış tek bir tanım bulunmamaktadır. Fakat Rex Harlow'un (1976, s.36), 472 farklı halkla ilişkiler tanımından yola çıkarak ortaya koyduğu "örgüt ve kamuları arasında karşılıklı anlayış, uzlaşı ve işbirliğine dayanan ayrıcalıklı bir yönetim fonksiyonu" tanımı genel olarak kabul görmekle birlikte halkla ilişkilerin yönetsel işlevine işaret etmektedir. Amerika Halkla illişkiler Derneği 2011-2012 yıllarında halkla ilişkiler tanımını modernleştirmiştir. Amerika Halkla ilişkiler Derneği'nin tanımı şöyledir: "Halkla ilişkiler örgütler ve kamu arasında karşılıklı yararlı ilişkiler kurmak için gerçekleşen stratejik bir iletişim sürecidir" (Görpe, 2013, s.287). Bu tanımda da halkla ilişkilerin karşııklı yarara yönelik amacı vurgulanırken, tanımda 'yönetim işlevi' emirkomuta zincirine yönelik bir çağrışım yaptığı için tercih edilmemiştir. Bunun yanında iletişimin stratejik olması gerektiği vurgulanmıştır (Görpe, 2013, s.287-288). Görüldüğü gibi, yönetsel tanımı ile ortaya çıkan halkla ilişkiler tanımı çağın gerekliliklerine göre değişip dönüşsmektedir. Günümüz internet çağında özellikle küreselleşmenin ve dijitalleşmenin artmasıyla ve teknolojide yaşanan gelişmeler sonucu küresel anlamda önemli bir kavrama dönüşmüştür.

Günümüzde internetin yükselişiyle halkla ilişkiler de bir dönüşüm geçirmiştir. Sosyal medya, halkla ilişkiler alanı için yeni olanaklar ve iletişim kanalları sunmaktadır. Coombs ve Holladay (2014), sosyal medyanın halkla ilişkiler üzerindeki etkisinin bir evrim niteliğinde olduğundan bahseder. Yeni kanallar, daha az kısıtlama ve etkileşim kurma olanakları halkla ilişkiler uygulamasında değişikliklere yol açmıştır (s.28). Halkla ilişkiler teknolojinin gelişimi ile ortaya çıkan değişikliklere uyum sağlamaktadır. Bununla birlikte, sosyal medyada geleneksel medyada olduğu gibi medya sahipliği söz konusu olmadığı için dijital mecralar fikirlerin özgürce ifadesi için kitlelere birçok olanak sunmaktadır. Fikirlerin sosyal medyada özgürce ifadesi ile demokratik toplumlar da gelişme göstermektedir. Çünkü Coombs ve Holladay'in (2014), dediği gibi demokratik toplumlar düşüncelerin özgürce ifade edilmesine dayanmaktadır (28). Bu durum da halkla ilişkilerin doğru bir şekilde gerçekleştirilmesi için bir olanak sağlamaktadır. Bunun yanında, sosyal medya kurumun ne yaptığı konusunda bir şeffaflık getirmiştir. Tapscott ve Ticoll (2003), internetin artık gizli olan şeyleri ortaya çıkarabildiğinden ve kurumların artık paydaşlarından bir şey gizleyemediğinden bahseder. Günümüz anında iletişim dünyasında, insanlar artık şirketleri mikroskopa koymaktadır (s.xi). 

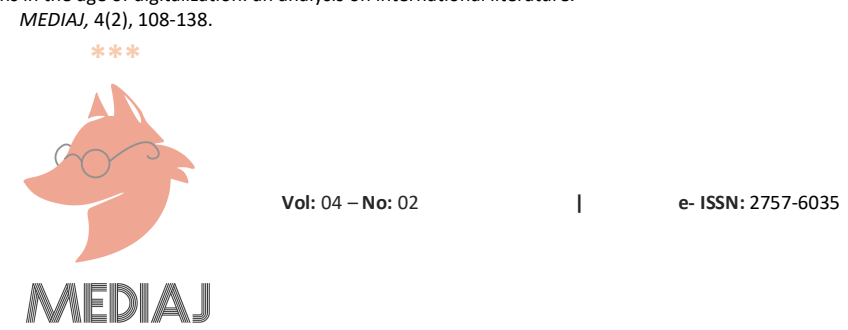

Dijitalleşmenin artmasıyla aktivist hareketler de daha çok görülür olmuştur. Larissa Grunig (2005, s.528) aktivizmi; eğitim, uzlaşma, ikna, baskı teknikleri aracılığıyla başka kamuları etkilemek üzere örgütlenmiş iki ya da daha fazla insanın oluşturduğu topluluk olarak tanımlar. Aktivizm bu anlamda, bir grup insanın sorunlu bulduğu uygulamaları değiştirmek için kurumlara uyguladığı baskıdır. Aktivist kuruluşlar bu konularda farkındalığı arttırmak, tutum ve davranışları değiştirmek için savaşırlar (Ciszek, 2015, s.447).

Genel olarak bakıldığında, 1960 ve 1970 'lerde aktivizmin yükseliş gösterdiği görülmektedir. Aktivist hareketlerin artmasıyla birlikte kurumlar açısından aktivist grupların davranışlarını öngörmek önem kazanmıştır. Bu sebeple kurumların halkla ilişkilere olan ihtiyacı da aktivist grupların ortaya çıkardığı sorunları çözme bağlamında artmıştır (Williams, 2008, s.437). Mintzberg (akt. Grunig, 2005, s.536), kurumlar ve aktivist gruplar arasındaki giderek artan çatışmanın nedenini şöyle açıklar: illk olarak, ekonomik gücün kurumların elinde toplanması kamuoyunu kaygılandırmaktadır. İincisi, kurumların elinde olan bu ekonomik güç giderek daha çok toplumsal sorunlara yol açmaktadır. Üçüncüsü, ekonomik ve toplumsal sorumluluklar bağlamında, insanların iş dünyasından beklentileri giderek artmaktadır. Grunig (2005, s.539), kurumlar ve aktivist gruplar arasındaki bu çatışmanın sonlanması için halkla ilişkilerin mükemmel halkla ilişkileri, çift-yönlü simetrik iletişimi gerçekleştirmesi gerektiğini vurgular.

Mükemmel halkla ilişkilerin uygulanması için etkili olabilecek altı değişken söz konusudur: Kültür, siyasal sistem, medya, ekonomik sistem, ekonomik gelişim düzeyi ve aktivizmdir. Bu altı bağlamsal durum her ülke için farklı olduğundan dolayı halkla ilişkiler çalışanları her ülke için bu değişkenleri göz önüne almalıdır (Grunig \& Grunig, 2005, s.14). Görüldüğü gibi aktivizm mükemmel halkla ilişkilerin uygulanmasında önemli altı ilkeden biridir. Mükemmellik teorisine göre aktivizm, kurumun halkla ilişkiler uygulamalarını geliştirir. Çünkü kurumlar aktivist bir olayla karşılaştıklarında iki-yönlü simetrik iletişim kullanırlar. Aktivist faaliyetler kurumun hükümet düzenlemelerinden korkmasına ve bunlara uymasına neden olur. Aktivizmle karşılaşıldığında halkla ilişkiler yönetimsel bir rol alır ve stratejik yönetime dâhil olur. Daha çok simetrik bir iletişim tercih edilir, katılımcı bir kültür gelişir, organik bir yapı ile kurum çevresine karşı açık olur. Bu sebeple aktivizm, kurumların mükemmel halkla ilişkileri geliştirmesinde faydalı olmaktadır (Ciszek, 2015, s.450).

Grunig'in (2005, s.551) yaptığı çalışmaya göre, kurumlar aktivist gruplarla kurdukları ilişkilerde başarılı olamamıştır. Bunun sebebi, kullandıkları halkla ilişkiler modelidir. Genel olarak bakıldığında, basın ajansı modeli, kamuoyu ve iki yönlü asimetrik modeller kullanılmaktadır. Çift yönlü simetrik model yaygın olarak kullanılmamaktadır. Fakat mükemmel örgütler, yalnızca kurumun çıkarlarını değil, aynı zamanda çalışanlarının ve tüm ilgili kamuların çıkarlarını gözetmek için iki yönlü simetrik iletişim kullanırlar. Kurumlar bir sorun ortaya çıktığında iki yönlü iletişime başvurmalıdır; çünkü artık "sorundan haberleri yoksa sorunları da yoktur" düşüncesi geçerli değildir. Günümüz internet çağında simetrik iletişim bir gereklilik olmuştur. Wakefield'a (2007, s.149) göre, simetrik iletişimin temelleri internetin bir iletişim mekanizması olarak ortaya çıkmasından önce atılmış olsa da internet simetrik iletişimin gerekçesini güçlendirmektedir. Bu bağlamda, halkla ilişkiler uygulayıcısı, çalıştığı kurum bir sorunla karşılaştığında kurum ve aktivist grup arasında bir arabulucu olarak çalışmalıdır. Kurumun buyruklarını yerine getirmek yerine kurum ve aktivist gruplar için kazan-kazan durumu yaratmalıdır. Aktivist gruplarla iletişime açık 


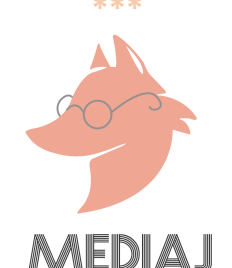

olunmalı ve uzlaşma olasıllığının vurgulanması gerekmektedir (Grunig, 2005, s.552). Böylece sorun ortaya çıktığında hemen ele alınarak ve aktivist gruplara güven verilerek sorunun bir krize dönüşmesi engellenmiş olacaktır.

Halkla ilişkilerde modern yaklaşım içerisinde yer bulan Mükemmellik çalışmasında, aktivizm kuruma yönelik dış kamular tarafından uygulanan bir hareket olarak ele alınmıştır ve kurumu iki yönlü simetrik iletişimi uygulamaya yönlendirip, etik davranış sergilemesini sağlayacak bir dış etken olarak görülmektedir. Bu durum her ne kadar dış kamuları da ilgilendiren bir durum olsa da temelde kurumun çıkarı, itibarı ön plandadır. Modern yaklaşımın sahip olduğu bu bakış açısının aksine, Holtzhausen (2000), postmodern yaklaşımın halkla ilişkiler alanında eleştirel bir bakış açısı sunabileceğini belirtmektedir. Böylece halkla ilişkilerin yalnızca bir yönetim fonksiyonu olmadığını; aynı zamanda aktivizm ve radikal politikalar aracılığıyla demokrasiye katkı sağlayabileceğini ifade etmiştir.

Dozier ve Lauzen (akt. Holtzhausen \& Voto, 2002), postmodern halkla ilişkiler yaklaşımında aktivist hareketlerin, toplumsal değişime, toplumsal düzenin temelden yapısökümü ve yeniden inşasına neden olduğundan bahseder (s.60). Postmodern halkla ilişkiler yaklaşımında halkla ilişkiler çalışanları kurumsal aktivistler olarak hareket etmektedir. Halkla ilişkiler çalışanları, etik olarak karar verme, değişim için arzu, baskın güç karşısında biyoiktidarı kullanma, çalışanları temsil etmek için bir kaygı, fikir ayrılığı pratiği aracılığıyla kurumsal aktivizmi sergilerler (Holtzhausen \& Voto, 2002, s.57). Holtzhausen'e (2000) göre, halkla ilişkiler çalışanları eğer çalıştıkları kuruluşlarda aktivist bir duruş sergiler ise, halkla ilişkiler uygulaması daha etik olabilir. Halkla ilişkiler çalışanları bu rolde, örgütün vicdanı olarak hizmet edebilir, kurum ve örgüt ilişkisinde gücü elinde bulundurmayanlara ses verebilir. Bu bağlamda kurumlarda aktivist halkla ilişkiler faaliyetlerinin gerçekleştirilmesinin çevresel ve toplumsal sorunlara çözüm sunabileceği ve hem kamu hem de kurum açısından uzun süreli fayda sağlayabileceği söylenebilir. Bu konudaki dünyadaki çalışmalara bakıldığında, tüm dünyada gerçekleşen H\&M markasının çevresel konulara dikkat çekmek için uyguladığı geri dönüşüm kampanyası, Shell'in iklim değişikliği ile mücadele kapsamında "Make the Future" adlı sürdürülebilir ve yenilenebilir enerji konusundaki kampanyası örnek verilebilir. Ülkemizde ise bu konudaki çalışmalara bakıldığında, Orkid markasının toplumdaki cinsiyetçi önyargılara karşı gerçekleştirdiği "kız gibi yap" kampanyası örnek gösterilebilir.

\section{YÖNTEM}

Bu çalışmada, halkla ilişkiler alanıyla ilgili uluslararası literatürde yeni tartışmaların yer aldığı uluslararası üç dergi olan Public Relations Review, Public Relations Inquiry, Journal of Public Relations Research dergilerinde "aktivist halkla ilişkiler" ve "dijital medya" konularının kesiştiği çalışmalar incelenmiştir. Public Relations Review, Public Relations Inquiry, Journal of Public Relations Research dergilerinin seçilmesinin sebebi, bu dergilerin halkla ilişkiler alanında önde gelen uluslararası dergiler olmalarının (Botan \& Taylor, 2004) yanında, söz konusu dergilerin Web of Science'ta taranmasıdır. Bu dergiler seçilirken Scimagojr sayfası üzerinden kontrol edildiğinde Public Relations Review dergisinin iletişim dâhil her kategoride (pazarlama, örgütsel davranış ve insan kaynakları yönetimi) Q1'de tarandığı, Public Relations Inquiry dergisinin iletişim dâhil üç kategoride (dilbilim ve dil, strateji ve yönetim) Q1'de tarandığı, Journal of Public 


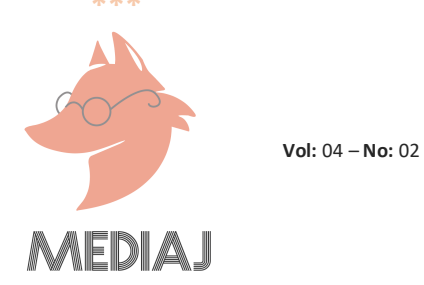

Relations dergisinin yer aldığı her kategoride (kamu yönetimi, sosyoloji ve siyaset bilimi) Q1'de tarandığı görülmektedir. ${ }^{7}$ Ayrıca bu dergiler, bu çalışmadaki araştırma konusunun da olduğu gibi halkla ilişkiler alanında yeni yaklaşımların, çalışmaların yayımlandı̆̆ı dergilerdir. Bu bağlamda söz konusu dergilerde 2000-2020 tarihleri arasında yayımlanmış ve aktivist halkla ilişkiler ve dijital medya konuları arasında bağ kuran makaleler analiz edilmiştir. 2000 yııının başlangıç olarak seçilmesinin nedeni, internetin bu tarihten sonra yaygınlaşmaya başlamasıdır (Wakefield, 2007, s.138).

Bu çalışmada sistematik inceleme yöntemine başvurulmuştur. Sistematik inceleme, belirli bir soruyu veya bir grup soruyu ele alarak kapsamlı bir literatür incelemesinin yanında eleştirel bir değerlendirme de gerçekleştirir (Vercic vd., 2015, s.143). Sistematik inceleme yöntemi, dijital medya ve aktivist halkla ilişkiler konusundaki uluslararası literatürdeki genel eğilimleri, yeni yönelimleri kapsamlı bir şekilde ortaya koymak ve elde edilen bu bulguların ülkemizde bu konu hakkında yapılacak çalışmalar için örnek teşkil etmesi amacıyla tercih edilmiştir. Sistematik inceleme yöntemi, belirli sorular etrafında araştırma konusu hakkında ilgili literatürü kapsamlı bir şekilde ele almaya imkân vermesi nedeniyle sosyal bilimlerde ve iletişim alanında gerçekleştirilecek literatür inceleme çalışmalarına uygun bir yöntemdir. Dünya'da sistematik inceleme yönteminin iletişim alanında kullanılmasına örnek olarak Vercic vd.'nin (2015) halkla ilişkilerde dijitalleşme üzerine yaptıkları çalışma gösterilebilir. Türkiye'de de iletişim alanında sistematik inceleme yönteminin kullanıldığı çalışma olarak Aktaş'ın (2021) stratejik iletişim araştırmaları konusunda uluslararası literatürü incelediği çalışması ve sistematik literatür incelemesinin içerik analiziyle birlikte kullanıldığı çalışma olarak Kıyan'ın (2019) iletişim teknolojileri ve toplumsal hareketler üzerine gerçekleştirdiği çalışma örnek verilebilir.

\section{Amaç ve Önem}

Dijital medyanın alternatif medya olarak ortaya çıkmasının aktivist halkla ilişkiler çalışmalarına nasıl katkı sağladığı sorunsalı etrafında şekillenen çalışmanın amacı, dijital medyanın aktivist halkla ilişkiler üzerindeki etkisini, önemini uluslararası literatür üzerinden ortaya koymaktır. Bu amaç etrafında bu çalışmada sistematik inceleme yöntemi ile uluslararası literatürdeki aktivist halkla ilişkiler ve dijital medya konusundaki genel eğilimler, güncel çalışma alanları ortaya konmuştur. Bu çalışmanın önemi, gelecekte yapılacak çalışmalara örnek teşkil etmesi açısından, yeni bir çalışma alanı olan ve sınırlı sayıda çalışmanın bulunduğu dijital medya ve aktivist halkla ilişkiler konusu hakkında yeni eğilim ve çalışma alanlarının üç uluslararası dergi üzerinden sistematik incelemesini sunmasıdır.

\footnotetext{
7 Bu dergiler seçilirken Scimagojr sayfası üzerinden 'public relations' anahtar kelimesi taratılmıştır. Arama sonucu adında bu anahtar kelimeyi içeren bes dergiye ulassılmıștır: Romanian Journal of Communication and Public Relations, Journal of Hospital Marketing and Public Relations, Public Relations Review, Public Relations Inquiry, Journal of Public Relations Research. Bu beş derginin 2020 yılı taranma verileri incelendiğinde Romanian Journal of Communication and Public Relations dergisinin yalnızca iletissim kategorisinde ve Q3'te tarandığı görülmüștür. Journal of Hospital Marketing and Public Relations dergisinin daha çok sağlık alanıyla ilgili olduğu ve tarandığı kategorilerde Q3 ve Q4'te tarandığı görülmektedir (Scimago, 2021). Bu sebeple bu iki dergi araştırmaya dahil edilmemiş, iletişim ve benzer kategorilerde Q1'de taranan Public Relations Review, Public Relations Inquiry ve Journal of Public Relations Research dergileri araştırma kapsamında incelemeye dâhil edilmiştir.
} 


\section{MEDIAJ}

\section{Araştırma Tasarımı ve Veri Toplama Araçları}

Sistematik inceleme yöntemi kullanılan bu çalışmada Victor'un $(2008$, s.3) sözünü ettiği aşamalara başvurulmuştur. Bunların ilki, araştırma sorularının belirlenmesi; ikincisi, araştırılacak anahtar kelimelerin belirlenmesi; üçüncüsü, incelenecek çalışmaların belirlenmesi; diğeri, nitelikleri değerlendirme ve son olarak da verilerin çıkarılması ve değerlendirilmesidir. Bu bağlamda öncelikle araştırma soruları belirlenmiştir. Çalışmanın ele aldığı sorunsal dijital medyanın aktivist halkla ilişkiler çalışmalarına nasıl katkı sağladığıdır. Bu anlamda, çalışmayı ortaya çıkaran ve çalışmaya yön veren sorular şöyledir:

S1) Dijital medya ve aktivist halkla ilişkilerin bağını kuran makalelerin incelenen dergiler özelinde dağılımı ne şekildedir?

S2) İncelenen dergilerde, dijital medya ve aktivist halkla ilişkiler bağını kuran makaleler ağırlıklı olarak hangi yıllarda yayımlanmıştır?

S3) Incelenen dergilerde, dijital medya ve aktivist halkla ilişkiler bağını kuran makalelerde ağırlıklı olarak hangi konular ele alınmıştır?

S4) Incelenen dergilerde, dijital medya ve aktivist halkla ilişkiler bağını kuran makalelerde ağırlıklı olarak kullanılan yöntemler nelerdir?

S5) İncelenen dergilerde, dijital medya ve aktivist halkla ilişkiler bağını kuran makalelerde dijital medyada aktivist halkla ilişkiler uygulayıcısı ağırlıklı olarak kimlerdir?

S6) İncelenen dergilerde, dijital medya ve aktivist halkla ilişkiler bağını kuran makalelere göre; kâr amacı gütmeyen kuruluşların (aktivist gruplar, STK'lar, toplumsal hareket örgütleri) dijital medyada gerçekleştirdikleri aktivist halkla ilişkiler uygulamaları nelerdir?

S7) İncelenen dergilerde, dijital medya ve aktivist halkla ilişkiler bağını kuran makalelere göre; kâr amacı güden kurumların dijital medyada gerçekleştirdikleri aktivist halkla ilişkiler uygulamaları nelerdir?

S8) Incelenen dergilerde, dijital medya ve aktivist halkla ilişkiler bağını kuran makalelerde aktivist halkla ilişkiler uygulaması için ağırlıklı olarak hangi dijital mecralar kullanılmıştır?

S9) İncelenen dergilerde yer alan dijital medya ve aktivist halkla ilişkiler bağını kuran makalelere göre; aktivist halkla ilişkiler etkinlikler hedef kuruluş üzerinde ne gibi sonuçlara yol açmaktadır?

S10) Incelenen dergilerde yer alan dijital medya ve aktivist halkla ilişkiler bağını kuran makalelere göre; aktivist halkla ilişkiler etkinliklerine, kurumların cevapları nasıl olmuştur?

Bu araştırma soruları belirlendikten sonra sistematik inceleme yönteminde ikinci aşama olarak, Public Relations Review, Public Relations Inquiry, Journal of Public Relations Research dergilerinde incelenecek olan makalelerin belirlenebilmesi adına taranacak anahtar kelimeler 


\section{MEDIAJ}

tanımlanmıştır. Dijital medya ve aktivist halkla ilişkiler bağını kuran makalelere ulaşmak için, incelenen dergilerde "aktivist halkla ilişkiler" ve "dijital medya" anahtar kelimeleriyle birlikte dijital medya ile ilgili olabilecek terimler araştırmaya dâhil edilmiştir.

Tablo 1. Anahtar Kelimeler

\begin{tabular}{|c|c|}
\hline $\begin{array}{l}\text { Anahtar } \\
\text { Kelimeler }\end{array}$ & $\begin{array}{ll}\text { - } & \text { Aktivist halkla ilişkiler } \\
\text { - } & \text { Dijital Medya } \\
\text { - } & \text { Yeni Medya } \\
\text { - } & \text { Sosyal Ağlar } \\
\text { - } & \text { Sosyal Paylaşım Platformları } \\
\text { - } & \text { Internet } \\
\text { - } & \text { Website } \\
\text { - } & \text { Dijitalleşme } \\
\text { - } & \text { Sosyal Medya } \\
\text { - } & \text { Facebook } \\
\text { - } & \text { Twitter } \\
\text { - } & \text { Instagram } \\
\text { - } & \text { Youtube } \\
\text { - } & \text { Tumblr } \\
\text { - } & \text { Wikiler } \\
\text { - } & \text { Blog } \\
\text { - } & \text { Podcast } \\
\text { - } & \text { Google+ } \\
\text { - } & \text { Linkedin }\end{array}$ \\
\hline
\end{tabular}

Bu anahtar kavramlar belirlendikten sonra, incelemenin üçüncü aşaması olarak belirlenen anahtar kavramlar ile arama yapılarak incelenen dergilerin 2000-2020 yılları arasında yayımlanan makalelerine ulaşıımıştır. Sistematik incelemeye dâhil edilecek makaleleri belirlemek adına ortaya çıkan makalelerin başlıkları, özetleri, anahtar kelimeleri incelenerek 'aktivist halkla ilişkiler' ve 'dijital medya' üzerine yazılmış makaleler seçilmiştir. Bu bağlamda, incelenen dergilerde, belirlenen kriterlere uyan toplam 16 çalışmaya ulaşılmıştır. Bunlardan $15^{\prime} \mathrm{i}$ makale $1^{\prime} i$ ise editör yazısıdır. Bu sebeple 15 makale değerlendirmeye alınmıştır. Bu durum, bu çalışma konusunun ne kadar yeni bir alan olduğunun bir kanıtıdır. Bu makaleler sistematik inceleme yöntemiyle analiz edilmiştir ve araştırma soruları çerçevesinde bulgular araştırma sorularına cevap verecek şekilde başıılar halinde ortaya konmuştur. Ayrıca literatür incelemesinin genel çerçevesini sunan bir tablo oluşturulmuştur ${ }^{8}$. Çalışmanın araştırma soruları ve elde edilen bulgular söz konusu üç dergide belirlenen kriterlere göre seçilen makaleler özelinde ele alınmıştır. Analiz sonrası elde edilen bulgular değerlendirme ve sonuç bölümünde araştırma soruları eşliğinde ele alınarak sentezlenip, çalışmalardaki temel eğilimler ortaya konmuştur.

\footnotetext{
${ }^{8}$ Ek1'de tabloya yer verilmiştir.
} 


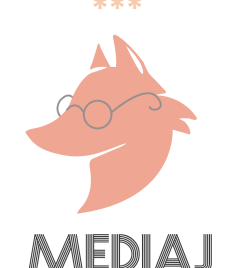

Çalışmanın güvenirliğine bakıldığına Krippendorff'un (1980) güvenirlik için bahsettiği üç türden (kararlılık, tekrarlanabilirlik ve doğruluk) tekrarlanabilirlik türüne uymaktadır. Çünkü söz konusu çalışma belirtilen kriterler çerçevesinde farklı koşullar altında, farklı zamanlarda farklı yerlerde, farklı kişiler tarafından tekrar edildiğinde aynı sonucu verecektir. Çalışmanın geçerliğine bakıldığında, dijital medyanın aktivist halkla ilişkiler çalışmalarına nasıl katkı sağladığı sorunsalı çerçevesinde üç dergi sistematik bir şekilde analiz edilmiş ve yöntem kısmında ayrıntılı olarak anlatımıştır. Kullanılan metodolojik yöntem, veri toplama süreçleri, verilerin analizi ve yorumlanması tutarlıdır. İzlenen çalışma tasarımı çalışılan konu hakkında sonuçları ortaya çıkarmada yeterli bir yöntemdir. Bu bağlamda çalışmada bir iç geçerlilik söz konusudur.

Bu çalışmanın sınırlııklarına bakıldığında öncelikle ele alınan konu yalnızca üç dergi üzerinden ele alınmıştır ve daha önce benzer bir çalışma bulunmadığı için bir karşılaştırma yapılması mümkün olmamıştır. Bu sebeple bu konu hakkında gelecekte yapılacak çalışmaların aynı dergiler üzerinden farklı yılları kapsayacak şekilde veya farklı dergiler üzerinden ele alınıp bu çalışma ile karşılaştırılma yapılması alana katkı sağlayacaktır. Çalışmaya dair diğer bir sınırlılık ise taranan anahtar kelimeler arasında yer alan dijital mecraların farklı tarihler arasında ortaya çıkmış olmasıdır. Örneğin 2010 yılında ortaya çıkan İnstagram ya da 2011 yılında ortaya çıkan Google Plus dijital araçlarının özelindeki çalışmaların sayısının diğerlerine göre sınırlı kalması olasıdır. Fakat çalışmanın konusu dijital medya ve aktivist halkla ilişkiler üzerine olduğu için dijital medyaya işaret eden kavramların kullanılması kaçınılmazdır. Bununla birlikte, bu yeni mecraların gelecekte yapılacak benzer çalışmalarda daha çok ele alınması olasıdır. Örneğin İnstagram hem fotoğrafların hem fikirlerin hem de seslerin paylaşımına imkân veren bir mecra olduğu için çalışma konusu olan dijital medyada aktivist halkla ilişkiler bağlamında elverişli bir mecradır.

\section{BULGULAR}

\section{Makalelerin Yayımlandığı Dergiler (S1), Yıllar (S2), Makalelerde Ele Alınan Konular (S3) ve Kullanılan Yöntemler (S4)}

Dijital medya ve aktivist halkla ilişkiler bağını kuran makaleler ağırlıklı olarak Public Relations Review dergisinde yayımlanmıştır. Çalışmada belirlenen kriterlere uygun olarak üç uluslararası dergide toplam 15 makaleye ulaşılmıştır. Bu makalelerin 8'i (M1, M2, M3, M4, M5, M6, M7, M8) Public Relations Review, 4'ü (M9, M10, M11, M12) Journal of Public Relations Research ve 3'ü (M13, M14, M15) Public Relations Inquiry dergilerinde yayımlanmıştır. Bu bağlamda Şekil1'de de görüldüğü gibi, belirlenen kriterlere göre tespit edilen ve incelenen makalelerin yarısından fazlasının Public Relations Review dergisinde yayımlandığı görülmektedir. Bu bulgular bağlamında, dijital medya ve aktivist halkla ilişkiler ilişkisini kuran çalışmalar gerçekleştirecek araştırmacıların bu alanın kuramsal ve kavramsal eğilimlerin üç dergi arasından ağırlıklı olarak Public Relations Review dergisi üzerinden takip edilebileceği söylenebilir. 


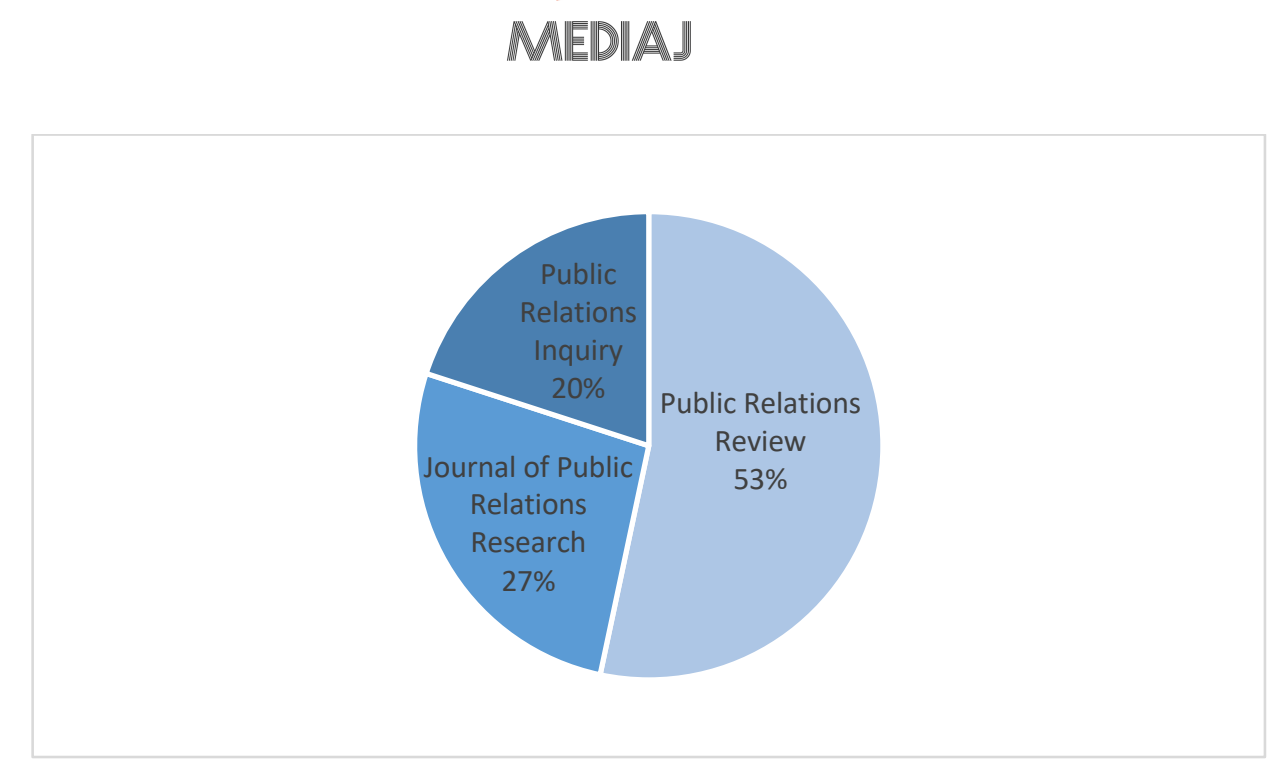

Şekil 1. Makalelerin Dergilere Göre Dağııımı

Dijital medya ve aktivist halkla ilişkiler bağını kuran makalelerin hangi tarihlerde yayımlandığını Şekil2 üzerinden görebiliriz. Buna göre; çalışmalardan 3'ü (M1, M9, M10) 2000-2010 tarihleri arasında, 12'si (M2, M3, M4, M5, M6, M7, M8, M11, M12, M13, M14, M15) ise 2010 sonrası yayımlanmıştır. Bu bulgulara göre, dijital medyanın aktivist halkla ilişkiler ile bağını kuran makalelerin ağırııkı olarak 2010 sonrası dönemde yayımlandığı görülmektedir. Bu durumun ortaya çıkmasında, Facebook, Twitter ve Youtube gibi çok kullanılan dijital medyaların 2000'in ikinci yarısından sonra; İnstagram'ın ise 2010 yılında ortaya çıkmasının bir etken olması olasıdır. Ayrıca henüz ortaya çıkışları yeni olan bu mecralarda aktivist halkla ilişkiler etkinliklerinin gerçekleştirilmesi de yeni bir uygulama alanıdır. Bu bulgular bağlamında, gelecekte bu konuda yapılacak çalışmalarda araştırmacılar bu dergilerde 2010 ve sonrası dönemde daha çok çalışmaya ulaşabilirler.

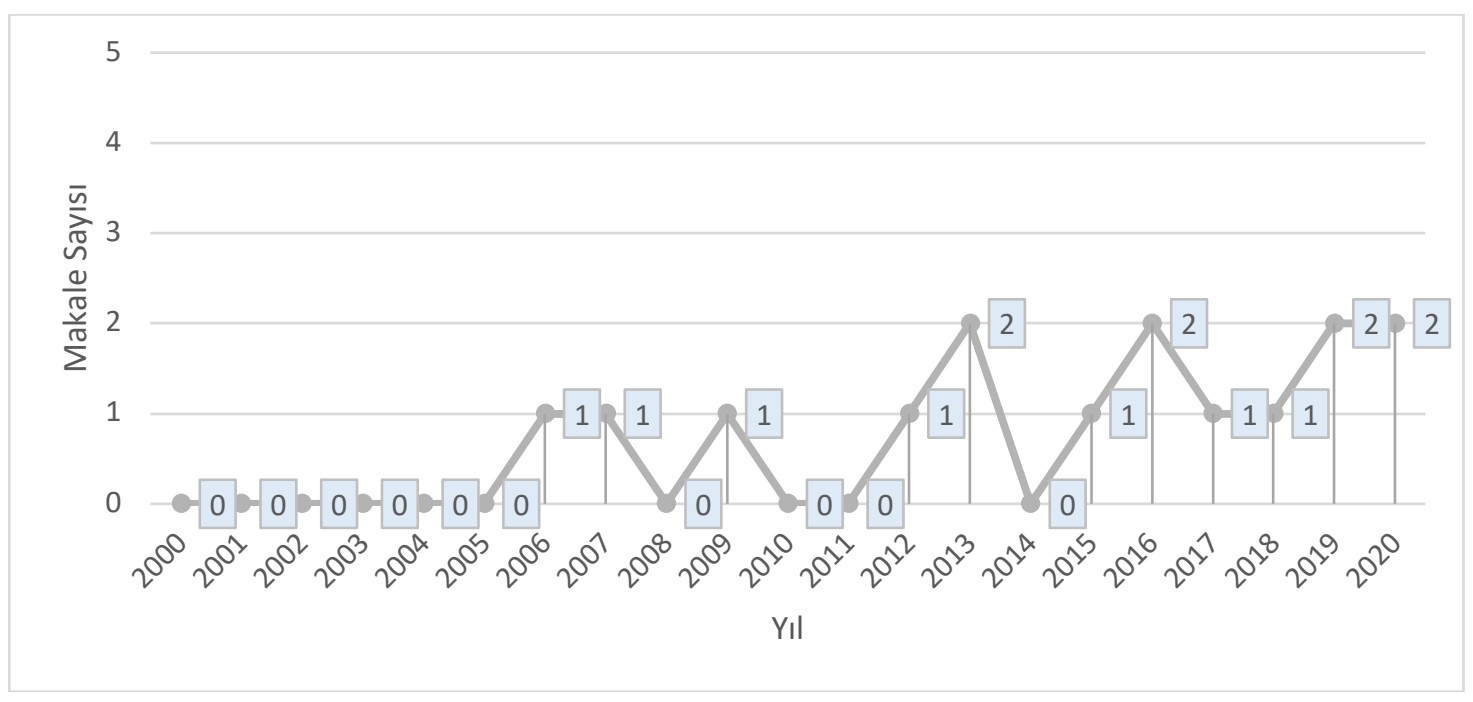

Şekil 2. Makalelerin Yıllara Göre Dağııııı 


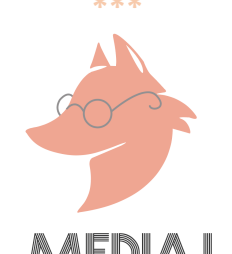

Dijital medya ve aktivist halkla ilişkiler bağını kuran makalelerdeki konulara bakıldığında ağırıklı olarak işlenen konunun, kâr amacı gütmeyen grupların (aktivist gruplar, STK'lar, toplumsal hareket örgütleri) hedef kuruluşa karşı gerçekleştirdikleri çevrimiçi aktivist halkla ilişkiler etkinlikleri (M3, M4, M5, M8, M14) üzerine olduğu görülmektedir. Ağılıklı olarak ele alınan bu konuyu, aktivist grupların websiteyi aktivist halkla ilişkiler etkinliklerinde nasıl kullandığı (M2, M9, M11) ve aktivistlerin toplumsal sorunlar hakkında dijital medya üzerinden gerçekleştirdikleri aktivist halkla ilişkiler (M7, M12, M13) konuları takip etmektedir. İncelenen diğer makalelerde, kâr amacı güden kuruluşların toplumsal (M6) ve çevresel (M15) sorunlar üzerine dijital medyada gerçekleştirdikleri aktivist halkla ilişkiler; aktivistlerin etkinliklerinde dijital medyayı nasıl kullandıkları (M1); internet ve aktivizm üzerine kuramsal tartışmalar (M10) konuları ele alınmıştır. Bu bulgular ele alındığında ağırlıklı olarak kâr amacı gütmeyen kuruluşların dijital medyada gerçekleştirdikleri aktivist halkla ilişkiler konularında çalışmalar yapıldığı görülmektedir. Bu bulgular ışığında, incelenen bu makaleler de örnek alınarak Türkiye özelinde yapılacak bir çalışmada aktivist grupların hedef kuruluşlar üzerine dijital medyada gerçekleştirdikleri aktivist halkla ilişkiler etkinliklerinin incelenmesi alana katkı sağlayacaktır. Bununla birlikte dijital medyanın aktivist halkla ilişkilere etkileri, bu grupların websitelerinin incelendiği ve dijital medyayı nasıl daha etkili kullanabileceklerine yönelik çalışmaların gerçekleştirilmesi bu alana katkı sağlayacaktır. Bunun yanında kâr amacı güden kuruluşların gerçekleştirdikleri dijital aktivist halkla ilişkiler konularının az olmasının sebebinin bu konuda yeterli örnek olayın olmaması muhtemeldir. Bu konuda araştırmacıların karşısına çıkan örnek olayların incelenmesi hem alana katkı sağlayabilir hem de bu konuda şirketlere örnek teşkil edebilir.

Dijital medya ve aktivist halkla ilişkiler bağını kuran makalelerdeki kullanılan yöntemlere bakıldığında 4 çalışmanın (M2, M3, M7, M8) çoklu yöntem kullandıkları görülmektedir. İncelenen makalelerde ağırlıklı olarak içerik analizi (M2, M9, M11), tematik analiz (M5, M7, M12) ve vaka çalışması (M4, M6, M8) yöntemleri kullanılmıştır. Bununla birlikte biri çevrimiçi olmak üzere anket kullanan 2 makale (M1, M8) ve yine biri çevrimiçi olmak üzere derinlemesine görüşme kullanan 2 makale (M2, M13) mevcuttur. Diğer yöntemler yalnızca bir kez kullanılmakla beraber şöyledir: sosyal ağ analizi (M3), olay çalışması (M3), semantik ağ analizi (M7), literatür çalışması (M10), retorik analiz (M14) ve alımlama çalışması (M15). Incelenen makalelerden elde edilen bulgular ışığında, gelecek çalışmalarda aktivist halkla ilişkilerin gerçekleştirildiği dijital mecraların analizinde içerik analizi ve tematik analizin kullanılabileceği görülmektedir. Diğer en çok kullanılan yöntem olan vaka çalışması ise aktivist grupların ve kurumların gerçekleştirdikleri dijital aktivist halkla ilişkiler etkinliklerini ele alan çalışmalarda yöntem olarak kullanılabilir. Bununla birlikte dijital medyadaki aktivizmin araştırmasında anket ve derinlemesine görüşme gibi yöntemlerin çevrimiçi olarak da gerçekleştirilebileceği görülmüştür. 


\section{MEDIAJ}

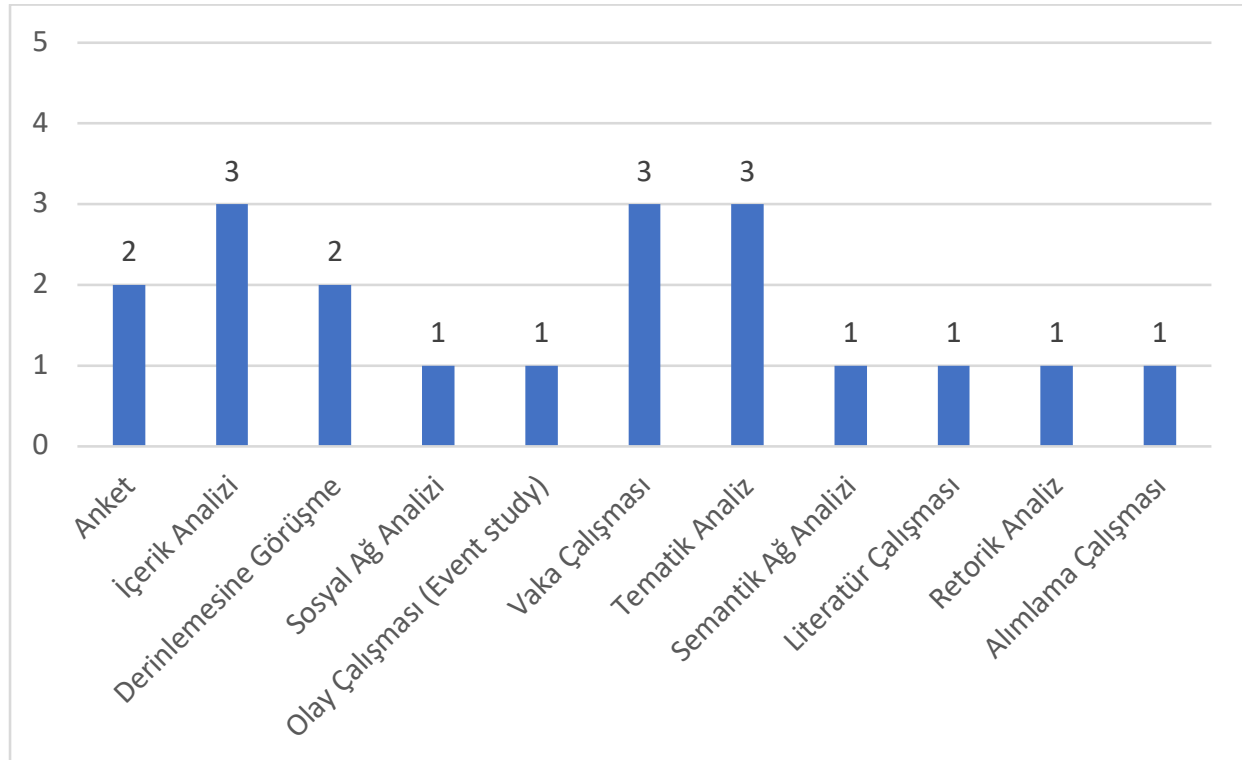

Şekil 3. İncelenen Makalelerde Kullanılan Yöntemler

\section{Dijital Medya Aracılığıyla Aktivist Halkla İlişkileri Uygulayan Aktörler (S5)}

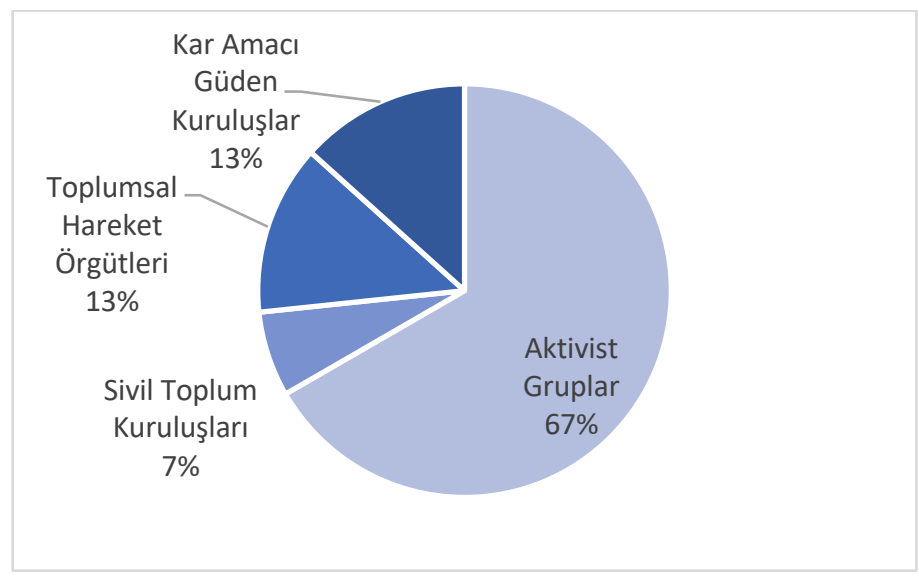

Şekil 4. Dijital Medyada Aktivist Halkla İlişkiler Uygulayıcıları

Public Relations Review, Public Relations Inquiry, Journal of Public Relations Research dergilerinde, dijital medya ve aktivist halkla ilişkiler bağını kuran makalelerde, dijital mecralarda aktivist halkla ilişkiler etkinliklerini gerçekleştiren ağırlıklı olarak aktivist gruplardır. Aktivist grupların temel aktör olduğu 10 makale (M2, M3, M4, M5, M8, M9, M10, M11, M12, M13), toplumsal hareket örgütlerinin olduğu 2 makale (M7, M14), STK'ların olduğu 1 (M1) ve kâr amacı güden şirketlerin olduğu 2 makale (M6, M15) bulunmaktadır. 


\section{MEDIIAJ}

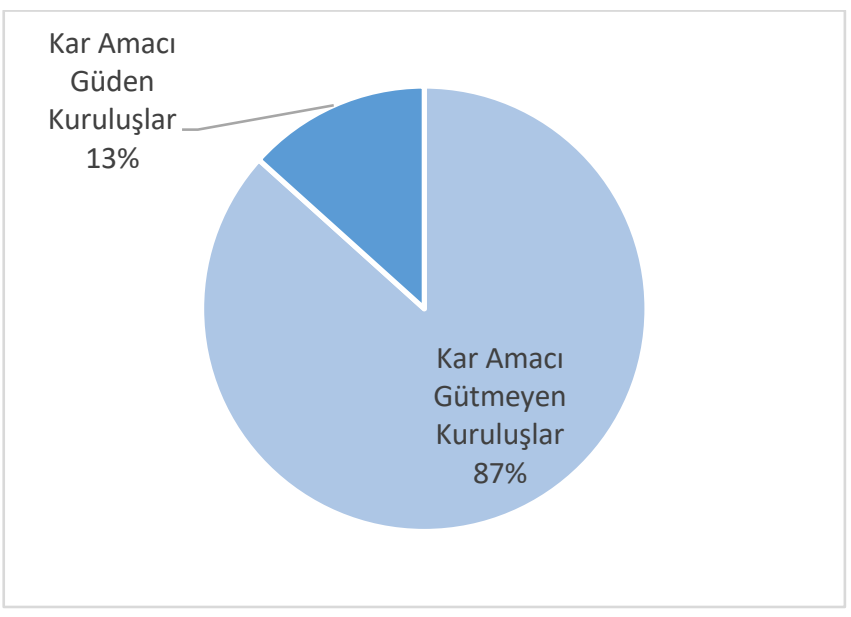

Şekil 5. Dijital medyada Aktivist Halkla ilişkiler Etkinlikleri Gerçekleştiren Gruplar

Bununla birlikte dijital medyada aktivist halkla ilişkileri uygulayan gruplar, bu pratikleri uygulama amaçları, ekonomik koşulları ve nihai amaçları çerçevesinde kâr amacı güden ve kâr amacı gütmeyen kuruluşlar olarak ikiye ayrılmıştır. Bu bağlamda kâr amacı güden kuruluşlar (şirketler) ve kâr amacı gütmeyen kuruluşlar (aktivist gruplar, STK'lar ve toplumsal hareket örgütleri) bağlamında ele alındığında kâr amacı gütmeyen kuruluşların daha ağırlıklı olarak dijital medyada aktivist halkla ilişkiler etkinliklerine başvurdukları görülmüştür.

\section{Kar Amacı Gütmeyen Kuruluşların (Aktivist Gruplar, Sivil Toplum Kuruluşları ve Toplumsal Hareket Örgütleri) Dijital Medya Aracılığıyla Gerçekleştirdikleri Aktivist Halkla iliş̧iler Uygulamaları (S6)}

Incelenen dergilerdeki dijital medya ve aktivist halka ilişkiler bağını kuran makalelerde, dijital mecralar aracılığıyla aktivist halkla ilişkiler etkinliklerini uygulayan aktörler ağırlıklı olarak aktivist gruplar, sivil toplum kuruluşları ve toplumsal hareket gruplarının yer aldığı kâr amacı gütmeyen kuruluşlardır. Demetrious (2013, s.26), amaçlarına ulaşmak için aktivist grupların yüzyılı aşkın bir süredir halkla ilişkiler faaliyetlerini uyguladıklarından bahseder. Bu açıdan bakıldığında, aktivistlerin kullandığı birçok taktik aslında halkla ilişkiler taktiği olduğu görülmektedir. Tarih boyunca insanlar, köleliği engellemeye, kadınların ve azınlıkların baskılanmasını azaltmaya, insanların sağlığını, refahını geliştirmeye yönelik halkla ilişkiler çalışmaları yürütmüşlerdir (Grunig akt. Ciszek, 2015: 447). Köleliğin kaldırılması yanlıları, kadınlara oy hakkı isteyenler ve işçi örgütleri halkla ilişkiler uzmanları gibi çalışmışlardır (Ciszek, 2015, s.447). Bunun yanında, özellikle 1960 'lar boyunca aktivistler kurumlarda halkla ilişkiler çalışanlarına iş vererek, halkla ilişkilerin modern araçlarından faydalanmışlardır (Coombs\&Holladay, 2014, s.63).

Aktivist gruplar, sivil toplum örgütleri ve toplumsal hareket örgütleri de halkla ilişkiler faaliyetlerini, kamuoyunu etkilemek ve sorunlu gördükleri yapıları ve uygulamaları değiştirmek gibi amaçlarla kullanmaktadırlar. Bu gruplar halkla ilişkileri bir iletişim aracı olarak kullanma konusunda kurumlarla benzer amaçları paylaşmaktadırlar (Smith, 2013, s.6-7). Seo vd. (2009, s.126), STK'ların çevrimiçi halkla ilişkiler faaliyetlerini, yeni medyanın daha çeşitli biçimlerini içerecek şekilde genişletmeleri gerektiğinden bahseder. Kuruluşların, kamu ile iki yönlü iletişimi 


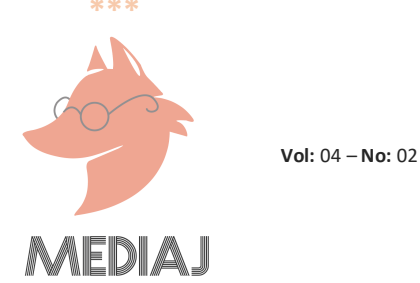

geliştirmek ve halkla ilişkiler faaliyetlerini buna göre belirlemek için dijital medya araçlarının potansiyelini fark etmesi gerekmektedir. Özellikle daha kısıtlı bütçeye sahip kuruluşların kurumsal imajı teşvik etmek ve fon toplama aracı olarak dijital medyayı daha yoğun ve kapsamlı bir şekilde kullanmaları önemlidir.

Incelenen makalelerde 13 makale $(M 1, M 2, M 3, M 4, M 5, M 7, M 8, M 9, M 10, M 11, M 12, M 13$, M14) aktivist gruplar, sivil toplum kuruluşları ve toplumsal hareket örgütleri tarafından dijital medya aracılığıyla gerçekleştirilen aktivist halkla ilişkiler faaliyetleri iken yalnızca 2 makale (M6, M15) kâr amacı güden kuruluşlar tarafından dijital mecralarda gerçekleştirilen aktivist halkla ilişkiler faaliyetleridir. Kâr amacı gütmeyen kuruluşların dijital medya aracılığıyla gerçekleştirdikleri aktivist halkla ilişkiler faaliyetlerinin genellikle toplumsal sorunlara dikkat çekmek, kâr amacı güden bir kuruluşun gerçekleştirdiği faaliyetler sonucu ortaya çıkan çevresel veya sosyal sorunlara karşı bir tepki koymak ve bu konuda değişim gerçekleştirmek amacıyla yapıldığı görülmektedir. Bununla birlikte, Chen (2020, s.101854) çalışmasında aktivistleri harekete geçiren bir etken olarak politik nedenleri öne sürmektedir. Bu çalışmada politize edilmiş tüketici aktivizmi, ekonomik nedenden ziyade politik nedenlerle hareket eden ve politik bir duruş sergileyen aktivizm olarak tanımlanır. Çalışmada bu aktivizm türüne, ABD'de Trump muhaliflerinin Trump ailesiyle ilgili markaları boykot etmeleri; Çinli internet kullanıcılarının, oyuncularından biri Tayvan'ın bağımsızlığının destekçisi olarak görüldügü için No Other Love filmini boykot etmeleri örnek olarak gösterilmiştir. Bu vakalarda örgütlerin, ekonomik tatminsizlikten ziyade politik nedenlerden dolayı harekete geçtikleri görülmektedir. Görüldüğü gibi aktivist gruplar, sivil toplum kuruluşları ve toplumsal hareket örgütleri ekonomik, ahlaki, sosyal, çevresel veya politik nedenlerden dolayı harekete geçebilmektedir.

Incelenen makaleler dijital medyanın aktivist halkla ilişkiler üzerindeki etkisini göstermektedir. Aktivist grupların gerçekleştirdikleri faaliyetlerin dijital medya sayesinde çok kısa zamanda küresel bir boyut alabildiği görülmüştür. Bu duruma örnek olarak Cizsek'in (2016, s.314) çalışması gösterilebilir. Çalışmasında Chick-fil A adlı işletmenin sahibinin yapılan bir görüşmede şirketin geleneksel evliliği savunduğunu, eşcinsel evliliklerin Tanrı'yı kızdıracağından bahsetmesiyle kurumun LGBT grupların tepkisini çekmesiyle başlayan anlaşmazlığı konu edinmiştir. Kurumun bu açıklamasını protesto etmek için aktivist gruplar sosyal medya aracılığıyla bir gecede birlik oldukları belirtilmiştir. Yine benzer bir şekilde dijital medyanın yarattığı etkiyi gösteren çalışma Honda'nın (2016, s.253-254), LGTBQ gençliğinin toplumsal baskıdan dolayı intihar etmesini konu edinen 'It Gets Better Project' kampanyasını incelediği çalışmadır. 2010'daki birden fazla LGTBQ gençliğinin intiharına yanıt olarak, köşe yazarı Dan Savage ve Terry Miller tarafından risk altındaki LGTBQ gençliğine, Youtube tabanlı proje olan 'It Gets Better Project' oluşturulmuştur. Bu dijital proje sayesinde LGTBQ yönelimlerinden birine ait olan yetişkinler, risk altındaki gençleri hedef alan videolu umut mesajları verilmiştir. Kampanya birden fazla çevrimiçi ve çevrimdışı platformu kapsamaktadır: Kampanya websitesi (www.itgetsbetter.org), resmi blog, yoğun sosyal medya görünümü (Facebook, Google+, Instagram, Tumblr, Twitter ve Youtube), kitap, TV. Proje beş yılın ardından, artan uluslararası LGTBQ zorbalık karşıtı ve intiharı önleme toplumsal hareketinin yüzü haline gelmiştir. Beş yıl içinde proje LGTBQ yönelimli ve müttefik bireyler tarafından 50 binden fazla video paylaşımına ve 50 milyondan fazla görüntülemeye ulaşmıştır. Bugün projenin beş kıtada uluslararası ortaklık programlarının yanı sıra çok sayıda üyelik programı bulunmaktadır. Proje LGTBQ genç tacizleri, 


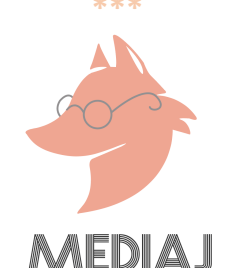

zorbalık ve intiharın yaygınlığı hakkındaki farkındalığın dünya çapında artmasına yardımcı olurken, uluslararası medyada da geniş yer bulmuştur. Bu proje, çevrimiçi tabanlı halkla ilişkiler kampanyasında sosyal medyanın rolünü anlamak için önemli bir örnektir.

Aktivist gruplar internetin gücünü kullanarak, toplumsal sorunlar veya çevresel konularda da tepkilerini ortaya koyarak küresel anlamda bir farkındalık ve değişim gerçekleştirebilme imkânına sahiptir. Toplumsal hareket örgütleri, nesli tükenmekte olan türler, iklim değişikliği, temiz su, feminizm, eşitlik gibi birçok konuyu savunup, desteklemektedir (Xiong vd., 2019, s.10). Edwards ve McCarthy'e (akt. Sommerfeldt \& Yang, 2017, s.830) göre, toplumsal hareket örgütleri çeşitli resmi ve resmi olmayan iletişim kanalları aracılığıyla, bireyleri sosyal değişim için ikna etmeye çalışır, harekete geçirirler. Bu konudaki incelenen çalışmalara bakıldığında, Xiong vd. (2019, s.10-11) tarafından gerçekleştirilen çalışmada toplumsal hareket örgütlerinin \#MeToo hareketinde, çevrimiçi mesajlar ve hashtagler kullanımının nasıl önemli bir rol oynadığı ele almıştır. Toplumsal hareket gruplarının \#MeToo kampanyası ile temel amaçları, cinsel saldırı ve şiddet mağdurları için bir destek topluluğu sağlamaktır. Kampanyanın websitesinde yer alan sonuçlarına bakıldığında, viral \#MeToo hashtagi sayesinde altı aydan kısa sürede cinsel şiddet hakkındaki hayati tartışma, ulusal bir diyalog haline gelmiştir. Yerel taban çalışması olarak başlayan kampanya, hayatın her kesiminden küresel bir topluluğa ulaşmış ve dünya çapında cinsel şiddetin genişliğini ve etkisini vurgulamıştır.

Bu gibi toplumsal hareketler sosyal medyanın gücünü kullanarak daha başarılı sonuçlara ulaşabilmektedirler. Buna bir diğer örnek, Vardeman ve Sebesta (2020, s.7-8) tarafından ele alınan sosyal medyadaki en büyük aktivist kampanyalardan biri olan 'Washington Kadınlar Yürüyüşü'dür. Washington Kadınlar Yürüyüşü, ABD tarihindeki en büyük koordineli aktivist hareket olarak bilinmekte ve halkla ilişkilerin toplumsal hareketlerdeki rolünü göstermektedir. Dijital medya araçları olarak, kampanyanın websitesi (WomensMarch.com), kampanyanın sosyal medya hesapları (Twitter, Facebook, İnstagram) kullanılmıştır. Sosyal medyadaki paylaşımlar incelendiğinde, Washington Kadınlar Yürüyüşü kamuları için politik bir değişim talep eden mesajların yer aldığı görülmektedir. Washington Kadınlar Yürüyüşü, kampanyanın bir gecedeki başarısı ve hem çevrimiçi hem de fiziksel yürüyüşler için takipçi kazanmak için kampanyanın küresel erişimi göz önüne alındığında sosyal medyayı kullanan en büyük aktivizm kampanyalarından biri olduğu görülmektedir (Vardeman \& Sebesta, 2020, s.14, 26).

Incelenen makaleler arasında Uysal ve Yang'ın (2013) gerçekleştirdiği çalışmada, internet çağında aktivist ağların gücü, WikiLeaks ve Bank of America arasındaki çatışma üzerinden ele alınmıştır. 2007 yılında faaliyete geçen bir aktivist grup olan ve hassas bilgileri ifşa eden WikiLeaks, sosyal medyanın aktivizm için gücünü gösteren en önemli sivil toplum kuruluşlarından biri olmuştur. 2010 yılında WikiLeaks, çok uluslu bir bankacılık ve finansal hizmetler şirketi olan Bank of America'yı (BOA) hedef almıştır. WikiLeaks ve BOA arasındaki bu savaşı internetin gücü ile WikiLeaks kazanmıştır ve BOA hisse senetleri hızla düşmüştür (Uysal \& Yang, 2013, s.459). Mükemmellik bakış açısından baktığımızda WikiLeaks gibi aktivist gruplar, doğası gereği otorite veya güçten yoksundur, sosyal değişimleri teşvik etmek için şirketlere güvenmek zorundadırlar (Uysal \& Yang, 2013, s.459). Fakat bu bakış açısı günümüz internet çağında geçerliliğini yitirmiştir. Bu bakış açısının aksine günümüzde internetin sağladığı güç ile aktivist gruplar sosyal değişimi gerçekleştirme konusunda oldukça güçlü ve etkilidir. Bu gruplar 
dijital medya sayesinde toplumsal değişimi gerçekleştirmeleri için kurumlara kolayca baskı uygulayıp, dünya çapında bir farkındalık yaratabilirler.

Botan ve Taylor (akt. Uysal \& Yang, 2013) halkla ilişkilerde baskın paradigma olarak kabul gören işlevselci yaklaşımın, kamularla birlikte anlamın inşa edildiği bir yaklaşım tarafından yerinden edildiğinden ve bu bağlamda bir paradigma değişiminin gerçekleştiğinden söz etmektedir (s. 460). Bu anlamda, halkla ilişkilerde mükemmellik ve simetrik iletişimin vurgulandığı işlevselci yaklaşım birçok eleştirel yaklaşım tarafından eleştiriye maruz kalmaktadır. Eleştirel yaklaşımlara göre aktivist gruplar, amacına ulaşmak için halkla ilişkilere başvurmaktadır ve dijital medya bu amacı yerine getirme konusunda en önemli araçtır.

\section{Kâr Amacı Güden Kurumların Dijital Medya Aracılığıyla Gerçekleştirdikleri Aktivist Halkla ílişkiler Uygulamaları (S7)}

Incelenen dergilerde yer alan ve dijital medya ve aktivist halka ilişkiler bağını kuran makalelerde, dijital mecralar aracılı̆̆ıla aktivist halkla ilişkiler etkinliklerini uygulayan aktörlerden bir diğeri de kâr amacı güden kuruluşlardır. Kâr amacı güden kuruluşların dijital mecraları kullanarak gerçekleştirdikleri aktivist halkla ilişkiler konusunu işleyen iki makale (M6, M15) yer almaktadır. Incelenen makaleler kapsamında, kâr amacı güden kuruluşların, kâr amacı gütmeyen kuruluşlara göre dijital medya aracılığıyla aktivist halkla ilişkileri daha az uyguladıkları görülmüştür. Kâr amacı güden kuruluşlarda aktivist halkla ilişkiler uygulaması daha önce bahsedildiği gibi, postmodern halkla ilişkiler anlayışına göre işlemektedir. Bu bağlamda, halkla ilişkiler çalışanının kurum ve kamu arasında aktivist gibi çalışması ve toplumsal sorunlar hakkında etik bir tavır sergileyerek kamunun ve çalışanların haklarını gözetmesi gerekmektedir. Bu durum kurumun kendisi için de geçerlidir. Kâr amacı güden kuruluşların, ortaya çıkmasında kendilerinin de sorumlu oldukları çevresel ve toplumsal sorunlar hakkında sürdürülebilir çalışmalar yürütmesi gerekmektedir. Fakat incelenen makaleler arasında yalnızca iki makale bu konuda örnek çalışmalar sunmaktadır. Kâr amacı güden kurumların dijital medya aracılığıyla gerçekleştirdikleri aktivist halkla ilişkiler faaliyetlerini konu edinen ilk çalışma, Demetrious (2019) tarafından gerçekleştirilen çalışmadır. Çalışmada Peabody Energy adlı kömür şirketinin çevresel sorunlara işaret eden, enerji yoksulluğunun hafifletilmesinde, temiz kömür fikrini teşvik etmek amacıyla gerçekleştirdiği 'Advanced Energy for Life' adlı halkla ilişkiler çalışması incelenmiştir. Kampanyanın medya duyurusunda, kampanyanın amacı, küresel enerji yoksulluğu krizi için farkındalık yaratmak olarak belirlenmiştir. Bu küresel kampanya ile düşük maliyetli elektriğe erişimi artırmak ve gelişmiş temiz kömür teknolojileri aracılığıyla emisyonları iyileştirmek amaçlanmıştır (Demetrious, 2019, s.9). Bu kampanya ile kurum küresel anlamda bir farkındalık oluşturmuştur. Sosyal bir meseleyi gündeme getirerek bu konuda örnek teşkil etmek ve bu uygulamaları arttırmanın öneminin yanında, toplumsal bir sorun hakkında, sürdürülebilir çözümler sunmak kurumların itibarı için de oldukça önemlidir.

Incelenen makaleler arasında kâr amacı güden kuruluşların dijital medyadan faydalanarak gerçekleştirdiği aktivist halkla ilişkileri konu edinen çalışma Allagui (2017) tarafından gerçekleştirilmiştir. Bu çalışmada kâr amacı güden kurumların da aktivist halkla ilişkilere başvurduğunu gösteren dört vaka analizinden bahsedilmiştir. Bu vakalar, genel olarak üç büyük markanın Birleşik Arap Emirlikleri'nde toplumda var olan eşitsizlikleri gösteren, bu konularda 


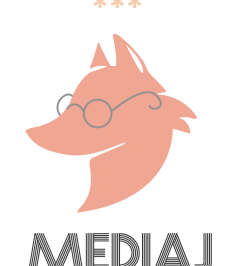

farkındalık yaratmayı amaçlayan kampanyalardır. Bu vakalar, postmodern halkla ilişkilerin ilgilendiği bir sorun olan toplumdaki eşitsizlikleri ortaya çıkarmakta ve sosyal medyanın halkla ilişkiler faaliyetlerindeki önemini göstermektedir (Allagui, 2017, s.262).

Bu vakalardan ilki, Sprite markasının Birleşik Arap Emirlikleri'nde Güney Asyalı iş̧̧ilere yapılan ayrımı ve marjinalleştirmeyi ortadan kaldırmak, bu insanları bir araya getirerek onlara daha iyi çalışma koşulları sunmak amacıyla gerçekleştirdiği ‘Sprite Kriket Yıldızları' kampanyasıdır. İkincisi Coca-Cola'nın 'Coca-Cola Mutluluğa Merhaba' adlı kampanyasıdır. Sprite'ın kriket kampanyasından sonra Coca-Cola da çalışanların yaşam koşullarına dikkat çekmek için "Merhaba Mutluluk" adlı bir kampanya düzenlemiştir. Diğer vaka yine Coca-Cola markasına ait olan 2016 yılında gerçekleşen 'Coca-Cola ile Mutluluğu Eve Getir' kampanyasıdır. Son vaka Emirates NBD Bankası tarafından engelli çocuklarla ilgili bir kampanyadır. Bu kampanya ile engelli çocukların acınmaya değil saygı duyulmaya ihtiyacı olduklarını göstermek amaçlanmıştır (Allagui, 2017, s.260-264). Üç markanın gerçekleştirdiği toplumsal sorunları konu edinen halkla ilişkiler kampanyaları ile ilgili videolar ve paylaşımlar sosyal medyada yayımlanarak küresel bir kampanya haline dönüşmüştür. Bu videolar milyonlarca izlenme sayısına ulaşmış ve bu kampanyalar hakkında binlerce tweet atılmış ve videolar Facebook, Twitter ve bloglarda paylaşılmıştır. Bu sayede toplumsal meseleler için küresel bir farkındalık oluşmakla birlikte bu markalar için kurumsal itibar anlamında olumlu bir etki de oluşturulmuştur.

Incelenen makalede markaların gerçekleştirdikleri bu dört kampanyanın da toplumdaki eşitsizliklere odaklandığı görülmektedir. Bu markalar sosyal medyayı kullanarak buradan bir tartışma başlatarak azınlık gruplarla ilgili bir gündem oluşturmuştur. Markaların sosyal medyayı kullanmalarının nedeni sosyal medyanın farkındalığın artmasında yardımcı olması, bu farkındalığın da destek için hayati öneme sahip olmasıdır. Sosyal medya özellikle ifade özgürlügünün sınırlı olduğu ülkelerde daha önemlidir. İnsanlar aktivizmlerini göstermek, bir durumu desteklediklerini ifade etmek için beğeni, paylaşım, fotoğraf ile sosyal medyaya başvurmakta ve desteğe gönüllü olduklarını bu içeriklerle ifade etmektedirler (Allagui, 2017, s.264).

Kâr amacı güden kuruluşların dijital medya aracılığıyla gerçekleştirdikleri aktivist halkla ilişkiler etkinliklerini konu edinen makaleler incelendiğinde; toplumsal veya çevresel bir konu hakkında kâr amacı güden kuruluşların gerçekleştirdikleri aktivist halkla ilişkilerin küresel bir farkındalığa ulaşabildiği görülmüştür. Sosyal medyanın bu farkındalığın yaratılmasında ne derece etkili olduğu ortaya konulmuştur. İncelenen makalelerde şirketler, markalar tarafından dijital mecralar kullanılarak gerçekleştirilen aktivist halkla ilişkiler sınırlı sayıdadır. Bu konuda çalışmalar yapacak araştırmacıların, örnek iki makalede olduğu gibi dünyadan ve Türkiye'den örnek olaylar ile bu konuyu ele alması halkla ilişkiler alanına katkı sağlayacaktır.

\section{Aktivist Halkla ilişkiler Uygulamalarında Kullanılan Dijital Mecralar (S8)}

Günümüz teknoloji çağında, internet her kurum için önemlidir; fakat aktivist gruplar ve kâr amacı gütmeyen birçok kuruluş için internetin hayati öneme sahip olduğu söylenebilir. Aktivist gruplar ilişkileri geliştirmek adına halkla ilişkiler faaliyetlerini internet aracılığıyla gerçekleştirerek hem düşük maliyet hem de hızlı erişim olanaklarından faydalanabilirler. Medya kurumlar için olduğu 
kadar aktivist gruplar için de hayati öneme sahiptir çünkü aktivizmde medya haberleri soruna meşruluk kazandırmaktadır. Gündem belirleme kuramına göre medya, meşrulaştırma işlevinin yanında aktivistlere statü kazandırır. Olien (akt. Grunig, 2005, s.534-535), aktivist hareketler sırasında medya tarafından izlenmenin kamuyu bilinçlendirmede ve hareketin başarısı ya da başarısızlığında oldukça önemli olduğundan bahseder. Fakat çoğu zaman, olay medyaya aktivist grubu destekleyecek şekilde yansımaz. Çünkü basın aracılığı ile ideolojik mesajları iletmek zordur ve medyanın çatışmayı yansıtması gerçekliğe uymamaktadır. Bunun sebebi, medyanın genel eğiliminin toplumsal hareketlerin haber değerini artırmak için, olayın tuhaf ve aykırı yönlerini abartmasıdır. Fakat günümüzde internetle birlikte aktivist grupların kendine yer bulabileceği birçok dijital mecra da ortaya çıkmıştır. İnternet, dünyayı küresel bir topluma dönüştürmüştür. Internete erişim ile birbirine bağlanmış aktivist grupları Vercic (akt. Wakefield, 2007, s.142), 'küresel savaşçılar' olarak adlandırmıştır. İncelenen makaleler arasında yer alan Reber ve Kim (2006, s.313) tarafından gerçekleştirilen çalışmaya göre, internet aktivist gruplar için ideal anlamda bir medya ilişkileri kurmaya hizmet edebilmektedir. Aktivist gruplar medyayı, medyada gündem oluşturmak için ve amaçlarını meşrulaştırmak için kullanmaktadır.

Incelenen dergilerde yer alan dijital medya ve aktivist halkla ilişkiler bağını kuran makalelerde dijital medya aracı olarak ağılıklı olarak website, Facebook ve Twitter'ın kullanıldığı görülmektedir. Bu dijital mecraları sırayla, bloglar, Youtube ve wikiler takip ederken ve aynı orana sahip olan Instagram, Google Plus, Weibo, Podcast, Videocast, Tumblr son sırada yer almaktadır. Websitenin dijital mecra olarak yer aldığı çalışmalarda, aktivist grupların websitelerinin incelenmesi (M2, M9, M1) ve website aracılığıyla gerçekleştiren aktivist etkinlikler (M12, M13, M14) inceleme konusu olmuştur. Dijital mecra olarak Facebook'u ele alan çalışmalarda (M1, M4, M5, M6, M12, M13) genel olarak sayfalar ve kullanıcı yorumları inceleme konusu olmuştur. Twitter'ı ele alan çalışmalarda (M1, M6, M7, M12, M13, M15) ise Twitter paylaşımları ve hashtag aktivizmi araştırma konusudur.

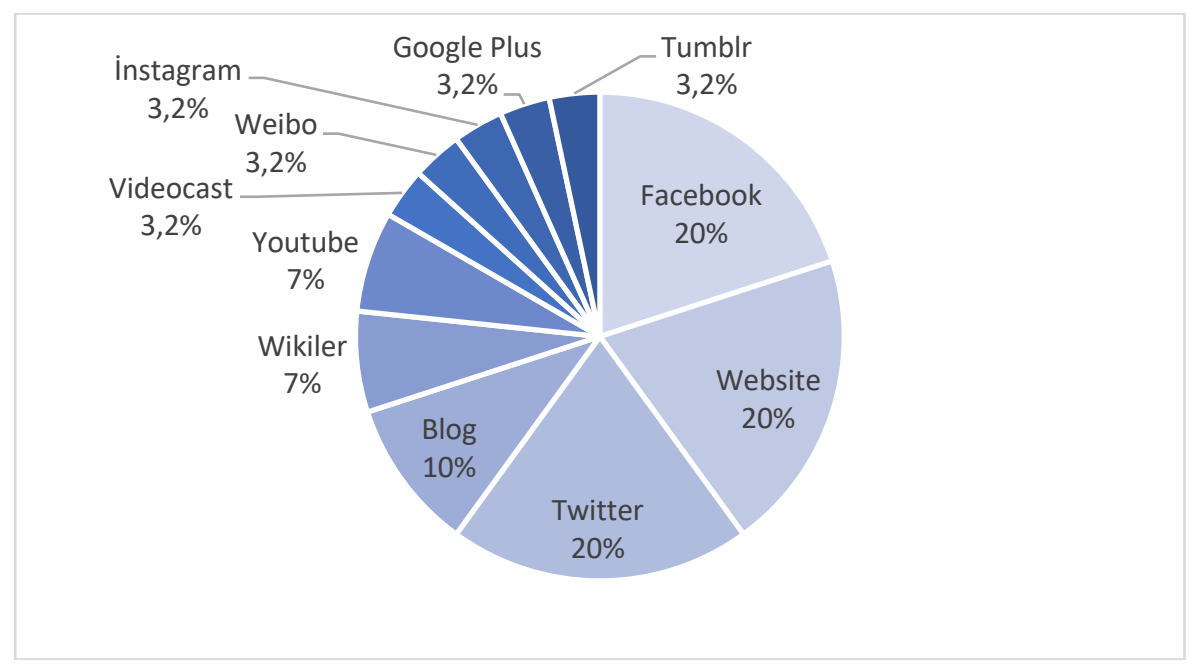

Şekil 6. Kullanılan Dijital Mecralar

Aktivist grupların dijital mecra olarak kendi websitelerinde bütün etkinlikleri paylaşmaları nedeniyle bu sonucun ortaya çıkması muhtemeldir. İncelenen makaleler arasında 


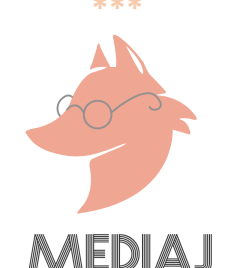

Sommerfeldt'ın (2013, s.347) çalışmasına göre; aktivist grup iletişiminde ve etkinliklerde kaynakların harekete geçirilmesinde website kullanılmaktadır. Websiteler konusunda yapılan diğer bir araştırmaya göre, website belirli bir sorun yönetiminde en etkili araç olarak görülmekte ve yüksek katılımlı kitlelere hitap etmektedir (Sommerfeldt vd., 2012, s.303). Bununla beraber incelenen makalelerde Twitter'ın fikirleri fotoğraflarla destekleyebilmesi ve dünya çapında gündem yaratmaya imkân vermesi; Facebook'un fikirlerin, görsellerin ve videoların takipçilerle kolayca paylaşımına izin veren bir mecra olması nedeniyle tercih edilmesi muhtemeldir. Günümüzde en çok kullanılan dijital mecralardan biri olan İnstagram'ın incelenen makalelerde çok az yer almasının sebebi ise diğerlerine göre daha yakın bir tarihte, 2010 yılında ortaya çıkmış olması olabilir. İnstagram'ın dijital mecra olarak ele alındığı çalışmanın (Vardeman \& Sebesta, 2020) yayımlanma yılı bu durumu destekler niteliktedir. İncelenen çalışmalarda bloglar, Youtube, Google Plus, videocast, podcast, Tumblr mecralarının destekleyici mecralar olarak kullanıldığı görülmektedir. Çin'de kullanılan bir dijital mecra olan Weibo ise Çin'de aktivist boykotlarını konu edinen çalışmada (Chen, 2020) ele alınmıştır. Wakefield (2007) tarafından gerçekleştirilen literatür çalışmasında genel olarak internet ele alınmıştır. Bu bulgular ışı̆̆ında, aktivist halkla ilişkileri inceleyecek çalışmaların, ağırlıklı olarak aktivist etkinliğin veya grubun websitesini, Facebook ve Twitter hesaplarını analiz edebileceği söylenebilir. Bununla birlikte, fikirlerin, görsellerin paylaşılabildiği; canlı yayınların, konserlerin gerçekleştirilebildiği; alanında ünlü birçok kişiyle etkileşime izin veren İnstagram'ı konu edinen çalışmaların bu konuyla ilgilenen araştırmacılar tarafından gerçekleştirilmesinin aktivist halkla ilişkiler alanına katkı sağlayacağı belirtilebilir.

\section{Aktivizmin Kurumlar Üzerinde Etkileri (S9) ve Kurumların Aktivizme Cevabı (S10)}

Incelenen dergilerde, aktivist grupların hedef kuruluşa yönelik dijital mecralarda gerçekleştirdikleri aktivist halkla ilişkiler etkinliklerini konu edinen çalışmalarda (M3, M4, M5, M8, M14), aktivizm ve internet üzerine olan literatür çalışmasında (M10) bu konu hakkında bulgulara ulaşılmıştır. Bu bulgular ışığında, genel olarak aktivizmin özellikle de dijitalleşme sonrası aktivizmin kurumlar için hayati öneme sahip olduğu görülmektedir. Alternatif medyanın yükselişi, aktivistlere ve kâr amacı gütmeyen kuruluşlara haberlerini, mesajlarını yaymak için yeni yollar sunmuştur. İnternetten önce aktivistlerin geleneksel medyada yer alması zordu ve bu gruplar amaçlarına ulaşmak için daha çok zaman, para ve emek harcamak zorundaydı. Friedman (akt. Wakefield, 2007), internet ile aktivizm küresel bir mesele haline geldiğini ifade eder. Internet aktivist gruplara daha iyi organize olma ve güç kazanma konusunda yardımcı olmuştur (s.151). Internetten önce aktivizm başladığı yerde kalırdı ve bu sayede bu olayları şirketler dünyanın geri kalanından saklayabilmekteydi. Fakat günümüzde bu durum imkânsızdır; internet sayesinde, bilgiler dünyanın geri kalanına saatler hatta dakikalar içinde ulaşabilmektedir. Aktivistler diğer gruplardan internet aracılığıyla yardım isteyebilmekte veya eylemlerini vurgulayabilmektedir. Hatta hükümetler bile dünyanın her yerinden insanların bir araya toplanarak hatalarını açığa çıkarmalarından korkmuş bir durumdadır. Günümüzde aktivist faaliyetler internet sayesinde sınır ötesi bir hal almıştır (Wakefield, 2007, s.151).

Küresel iletişim ile kurumlar bilgileri kontrol etmek ve yanlış yaptıkları şeyleri gizlemek zorundadır. Friedman (akt. Wakefield, 2007), "Dünyada hiçbir güvenli duvar kalmadı" der (s.150). Clarke'ye (akt, Wakefield, 2007) göre, hiçbir iletişim planı, eğer yalan söylüyorsa kurumu 
koruyamaz. Anında iletişim çağında, gerçek mutlakla ortaya çıkmaktadır (s.150). Aktivistler boykot, grev gibi kurumun medyada olumsuz yer almasına neden olacak faaliyetlerle kurumun gelirine ve itibarına zarar verebilir.

Dijital medya ve aktivist halkla ilişkiler bağını kuran makalelerden bu konuyu ele alan Uysal ve Yang'ın (2013) çalışmasında, WikiLeaks aktivist ağın Bank of America hisse değerlerini nasıl düşürdüğü ortaya konulmuştur. Bu konuyu ele alan diğer çalışmada Veil vd. (2015), çevrimiçi aktivistlerin Kraft Foods şirketinin sosyal medya hesaplarına karşı gerçekleştirdikleri çevrimiçi saldırının küresel bir boyuta ulaştığından ve şirketin kurumsal itibarına verdiği zarardan bahsetmektedir. Bu konuda Ciszek'in (2016) gerçekleştirdiği çalışmada, şirket ve kullanıcıları arasındaki görüş ayrılığı bulunması nedeniyle kullanıcıların sosyal medyayı kullanarak şirketi nasıl güçsüz kıldıkları ele alınmıştır. Chen (2020) tarafından gerçekleştirilen çalışmada ise, politik nedenlerden dolayı Lancome markasını boykot ettikleri örnek olay ele alınmıştır. Bu çalışmada herhangi bir üretim sorunu veya ekonomik neden olmaksızın yalnızca markayla görüşlerin uyuşmamasının bile aktivizm sebebi olabileceği ortaya konmuştur. Bu konuyu inceleyen Stokes ve Atkins-Sayre (2018) tarafından gerçekleştirilen son çalışmada, PETA'nın SeaWorld firmasını protesto etmek için dijital aktivizmi kullanması incelenmiştir. Gerçekleştirilen dijital aktivizm sonrası şirketin hisseleri yüzde 40 düşmüş, kârı yüzde 84 azalmış ve dijital aktivizm şirkette kurumsal politika değişikliğine sebep olmuştur. Incelenen makalelerden elde edilen bulgulara bakıldığında, dijital mecralarda gerçekleştirilen aktivist halkla ilişkiler etkinliklerinin hedef durumunda olan şirketleri hem ekonomik hem itibar hem de uyguladığı politikalar açısından olumsuz etkilediği görülmektedir.

Aktivist halkla ilişkiler etkinliklerine kurumların nasıl cevap verdikleri önemli bir konudur. Oliver (akt. Williams, 2008), aktivist bir etkinlikle karşılaştıklarında kurumların aktivist gruplara karşı verdiği beş yanıttan bahsetmektedir:

\footnotetext{
1.Eylemcilerin taleplerini kabul etmek, 2.Çoklu bileşenlerin bakış açılarının dengelenmesini, eleştirilerden uzak kalmayı ve anlaşmaya varabilmek için pazarlığı içeren uzlaşma, 3.Problemlerin gizlenmesi ve eylemlerin değiştirilmesi yoluyla ya da örgüt ve dışarıdaki baskı arasında bariyerler inşa etme yoluyla kaçınma, 4.Açık normları ve değerleri göz ardı ederek, yeni ihtiyaçlarla mücadele ederek ve kuruma baskı uygulayan kaynaklara saldırarak meydan okuma, 5.Etkili bileşenleri karşılıklı seçmek, örgütün algılarını etkilemek, örgütün etkilenebileceği süreçleri kontrol ederek manipüle etmek (s. 444-445).
}

İncelenen makalelerde kuruluşların, aktivistlerin taleplerini kabul ettiği veya uzlaşma yoluna gittiği bir durumla karşılaşılmamıştır. Genellikle kuruluşların aktivist hareketleri dikkate almadığı, sorunları yönetmediği ve bunun krizle sonuçlandığı görülmektedir. İncelenen makalelerde yer alan Wakefield'ın (2007) çalışmasında ele alınan Coca-Cola vakası, kuruluşların aktivist hareketleri yönetemediği duruma bir örnek sunmaktadır. Coca-Cola 1999 yılında, içeceklerdeki dioksin kalıntısının tüketicileri hasta ettiği konusunda bir küresel krizle karşı karşıya kalmıştır. Bu konuda marka hemen cevap vermemiş ve durum medyaya yansımıştır. Olayın üzerinden yedi gün geçince hükümet ürün yasağı kararı almıştır. Bu olay, kurumun genel merkezinin hemen cevap vermesi gerektiğine bir örnektir (s.147). Markanın sorun ortaya çıktığında proaktif bir şekilde, etkili bir sorun yönetimi ile sorunu çözmesi gerekmektedir. Eğer bunu yapmazsa örnekte de görüldüğü gibi var olan sorun bir krize dönüşebilmektedir. 


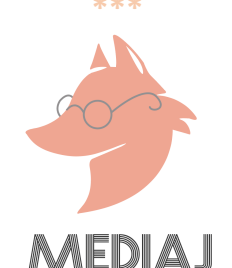

Bir diğer çalışmanın (Stokes, Atkins-Sayre, 2018, s.149) incelediği örnek vaka, SeaWorld markasını katil balinalara kötü muamele yapmakla suçlayan Blakfish adlı belgeselin 2013'te yayımlanmasıyla markanın bir halkla ilişkiler felaketiyle karşı karşıya kalmasıdır. SeaWorld, yanıt vermeye ve güvenilirliğini yeniden inşa etmeye çalışsa da aktivistlerin uyguladıkları stratejiler ile şirketin sıkıntıları derinleşmiştir. PETA-SeaWorld tartışması, zayıf kurumsal halkla ilişkilerin bir örneğini sunarken aynı zamanda aktivist bir grubun dijital teknolojiyi bilinçli kullanımı ile ulaşılan başarıyı göstermektedir. Bu vaka, dijital aktivist halkla ilişkiler kampanyalarının, hayvanları eğlence için kullanmak gibi tartışmalı bir konu hakkındaki toplumsal anlayışı nasıl yeniden şekillendirdiğini göstermektedir. Bu çalışma, stratejik, mesaj düzeyinde dijital aktivizmin toplumsal değişimi genişletmeye nasıl katkıda bulunduğunu ortaya koymaktadır.

Incelenen makaleler arasında, çevrimiçi aktivistlerin marka itibarına nasıl zarar verdiğini örnekleyen diğer çalışmada (Veil vd., 2015), Kraft markasına karşı gerçekleştirilen aktivist kampanya ele alınmıştır. Bu kampanyada, Babe adlı bloğun yazarı olan aktivist Vani Hari, Tesco'da takipçileri tarafından çekilen bir videoyu bloğunda paylaşmıştır. Bu video'ya göre, Kraft markasının ürün etiketlerinde "çocuklarda aktivite ve dikkat üzerinde olumsuz etkisi olabilir ve genetiği değiştirilmiş buğday içerebilir" yazmaktadır. Bu videoda ortaya atılan söylemler, New York Times ve çeşitli çevrimiçi medya kuruluşları tarafından hemen ele alınmışır. Kraft markası ise cevap olarak, markanın İngiltere'ye ürün ihraç etmediğini ve İngiltere'de Tesco'ya satış yapan bir distribütörü olmadığını belirtmiştir. Marka bunu yalanlasa da kısa süre içerisinde markanın itibarına zarar vermiştir (Veil vd., 2015, s.103).

Bununla birlikte, Hari'nin markaya karşı ilk girişimi olmadığı, bu olaydan bir ay önce bu konuda Change.org üzerinden bir kampanya başlattığı ortaya çıkmıştır. Bu örnek olay, çevrimiçi aktivistler ve halkla ilişkiler araştırmacıları için birçok çıkarım sunmaktadır: Geleneksel aktivist stratejiler çevrimiçi ortama uygulanmaktadır. Pasif aktivizmin değişime yol açmayacağı düşüncesi doğru değildir. Aktivist gruplar arasındaki işbirliğine dayanan ilişkiler hakkında daha fazla araştırma yapmak kurumlar için önemlidir. Proaktif sorun yönetimi stratejilerinin faydalarını kurumların görmesi gerekmektedir (Veil vd., 2015, s.103).

Incelenen makalelerdeki bulgular ışı̆̆ında, kurumların aktivist halkla ilişkiler etkinliklerini ve bunun sonucu ortaya çıkan sorun veya krizi iyi yönetemedikleri söylenebilir. Sorun yönetimi çalışmalarında kuruluşlar ortaya çıkan sorunlarda çevresini iyi araştırmalı ve bu sorunlar krize yol açmadan önce ele almak için proaktif çalışmalar gerçekleştirmelidir. Veil vd. (2015, s.107), bir ordu kurana kadar çevrimiçi aktivistleri görmezden gelmek yerine, kuruluşların tüketici endişelerini anlamak için doğru bir hat olarak çevrimiçi araçları benimsemesi gerektiğinden bahseder. Kuruluşlar eğer reaktif değişim stratejileri kullanmaya devam ederlerse, aktivistlerin kurumsal itibara zarar vermeye devam etmeleri muhtemeldir. Bu nedenle bir sorun çıktığında kurumların proaktif iletişim stratejileriyle sorunu çözmesinin hem toplumsal anlamda hem de kurumun itibarı açısından olumlu sonuçlar getireceği söylenebilir.

\section{DEĞERLENDIRME VE SONUÇ}

Dijitalleşmenin aktivist halkla ilişkiler üzerine etkilerini, Web of Science'ta taranan ve halkla ilişkiler uluslararası literatürü için önemli yere sahip ve güncel çalışmaların yer aldığı üç 
uluslararası dergideki literatür üzerinden sistematik inceleme yöntemiyle ele alan bu çalışma, dijital medyanın gücü ile aktivist halkla ilişkilerin artan önemini ortaya koymuştur. Bu çalışma ile aktivist gruplar, sivil toplum kuruluşları ve toplumsal hareket örgütleri gibi kâr amacı gütmeyen kuruluşlar tarafından gerçekleştirilen aktivist halkla ilişkiler faaliyetlerine kâr amacı güden kurumların da önem vermesi ve uygulaması gerektiğini öne sürmektedir.

Dijital medyanın aktivist halkla ilişkiler çalışmalarına nasıl katkı sağladığı sorunsalı etrafında gerçekleştirilen bu çalışmada, araştırma soruları bağlamında elde edilen bulgular incelenen dergiler özelinde değerlendirilmiştir. İncelenen makalelerin yer aldığı dergiler, yayımlandığı yıllar, makalelerde ele alınan konular ve kullanılan yöntemlere yönelik araştırma soruları kapsamında elde edilen bulgulara bakıldığında; öncelikle dijital medya ve aktivist halkla ilişkiler bağını kuran makalelerin yarısından fazlasının Public Relations Review dergisinde yer aldığı görülmüştür. Bu bulgu bağlamında, bu konuda araştırma yapacak araştırmacılara konunun kuramsal ve kavramsal eğilimlerinin bu üç dergi arasından Public Relations Review dergisi üzerinden takip edilebileceği önerilir. İncelenen makalelerin yayımlandıkları yıllara bakıldığında 2000-2010 arası yalnızca üç makale yayımlanırken; 2010-2020 arası dönemde 12 makale yayımlandığı görülmüştür. Bu durumda daha önce bahsedildiği gibi dijital mecraların ortaya çıkış tarihlerinin ve aktivist halkla ilişkilerin yeni bir araştırma konusu olmasının etkisi büyüktür.

Incelenen makalelerde işlenen konulara bakıldığında ağırlıklı olarak aktivist grupların hedef kuruma karşı gerçekleştirdikleri çevrimiçi aktivist halkla ilişkiler etkinlikleri konusu ele alınmıştır. Bununla birlikte aktivist grupların etkinliklerinde website ve dijital medyayı nasıl kullandıkları veya toplumsal sorunlar hakkında gerçekleştirilen aktivist halkla ilişkiler konusu da ele alınmıştır. Kâr amacı güden kuruluşların dijital medyada gerçekleştirdikleri aktivist halkla ilişkiler etkinliklerini ele alan çalışmaların sınırlı olduğu sonucuna ulaşıımışıı. Bu bağlamda, bu konu hakkında çalışma gerçekleştirecek araştırmacıların özellikle kâr amacı güden kuruluşların dijital medyada gerçekleştirdikleri aktivist halkla ilişkiler etkinliklerini ele alan çalışmalar yapması hem alana katkı sağlayacaktır hem de şirketlerin örnek alacağı şekilde bu konuda farkındalık yaratıp bu uygulamayı genişletecektir. Bununla birlikte, incelenen makalelerde araştırma konusu olan konular Türkiye'deki araştırmacılar tarafından Türkiye özelinde işlenirse, bu alanın ülkemizde gelişimini sağlayacaktır. İncelenen makalelerde kullanılan yöntemlere bakıldığında ağırlıklı olarak içerik analizi, tematik analiz ve vaka çalışması kullanılmıştır. Ayrıca anket ve derinlemesine görüşme yöntemlerinin çevrimiçi olarak da gerçekleştirildiği görülmüştür. İncelenen makaleler kapsamında, dijital mecraların analizini yapacak çalışmalarda içerik analizi ve tematik analizin; aktivist grupların hedef kurumlara karşı gerçekleştirdikleri aktivist halkla ilişkiler faaliyetlerini konu edinen çalışmalarda ise vaka çalışmasının tercih edilebileceği söylenebilir.

Incelenen makalelerde, dijital medya aracılığıyla aktivist halkla ilişkileri uygulayan aktörler ve uygulamaları incelendiğinde, dijital medyanın olanaklarından kâr amacı gütmeyen kuruluşların daha çok faydalandığı görülmektedir. Elde edilen bulgulara bakıldığında aktivist grupların, sivil toplum kuruluşlarının ve toplumsal hareket örgütlerinin ekonomik yönden kâr amacı güden kuruluşlara göre daha dezavantajlı olmalarına rağmen dijital medyanın rolünü fark edip bu gücü amaçlarına ulaşmak için etkili bir şekilde kullandıkları görülmektedir. Aktivist gruplar ve sivil toplum kuruluşları tarafından dijital medya aracılığıyla gerçekleştirilen aktivist halkla ilişkiler faaliyetlerinin hedef kuruluşlar için bir tehdit yarattığı ve krize yol açtığı görülmektedir. Aktivist 


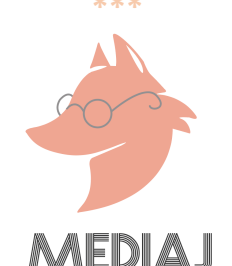

halkla ilişkiler faaliyetlerinin dijital medya aracılığıyla gerçekleşiyor olması krizin boyutunu arttırmakta ve kuruluşlar için kriz iletişimi artık daha çok önem kazanmaktadır. Bu sebeple postmodern halkla ilişkiler yaklaşımında olduğu gibi kâr amacı güden kuruluşların da topluma karşı daha duyarlı olması, çevresel ve toplumsal konular hakkında sürdürülebilir çalışmalar yürütmesi ve bünyesinde çalışan halkla ilişkiler çalışanlarının da aktivist gibi çalışması gerekmektedir. Fakat bu çalışmada incelenen makalelerde elde edilen bulgulara bakıldığında yalnızca iki makalede (M6, M15) kâr amacı güden kuruluşların aktivist halkla ilişkiler faaliyetlerini gerçekleştirdiği görülmektedir. Gelecekte yapılacak benzer çalışmalarda bu konunun tekrar ele alınması bu açıdan önem atfetmektedir.

Dijital medya ve aktivist halkla ilişkiler bağını kuran makalelerde, dijital mecra olarak ağırlıklı olarak website, Facebook ve Twitter'ın kullanıldığı görülmüştür. Aktivist grupların kendi websitelerinde gerçekleştirdikleri birçok etkinliği paylaşmaları buna bir neden olarak gösterilebilir. Facebook ise fikirlerin, görsellerin, videoların takipçilerle kolayca paylaşıldığı ve hedef firmaların gönderileri üzerinden yorumlarla etkinliklerin kolayca gerçekleştirilebileceği bir mecra olmasının tercih sebebi olması muhtemeldir. Twitter ise fikirlerin fotoğraflarla kolayca desteklenebildiği, hashtag ile kolayca dünya çapında farkındalık yaratmaya imkân sunması sebebiyle tercih edilmesi olasıdır. İncelenen çalışmalara bakıldığında, Facebook üzerinden kullanıcı yorumları ile, Twitter üzerinden hashtag aktivizmi ile, website üzerinden ise bilgilerin ve kaynakların harekete geçirilmesiyle aktivist halkla ilişkiler etkinliklerin gerçekleştirildiği görülmektedir. Bunun yanında günümüzde popüler bir uygulama olan İnstagram'ın dijital mecra olarak kullanıldığı yalnızca bir makaleye (Vardeman\&Sebesta, 2020) ulaşılmıştır. Bunun sebebinin 2010 yılında ortaya çıkan yeni bir uygulama olması muhtemeldir. Yapılan çalışmanın tarihine de bakıldığında 2020 yılında yayımlanmış olması bu durumu desteklemektedir. Fakat hem fikirlerin hem görsellerin paylaşılabildiği, canlı yayınların gerçekleştirilebildiği, dünyada her alanda önemli kişileri takip etmeye ve onlarla etkileşime geçmeye imkân veren bir dijital mecra olması sebebiyle aktivist halkla ilişkiler etkinliklerin gerçekleştirilmesi için uygun bir alan sunmaktadır. Bu sebeple İnstagram'ı konu edinen çalışmaların gerçekleştirilmesi halkla ilişkiler ve aktivizm alanına katkı sağlayacaktır. Instagram'ı konu edinen çalışmaların farklı dergiler üzerinden veya farklı zamanlarda yapılması veya örnek olaylar üzerinden konunun ele alınması alanın gelişimini sağlayacak önemli araştırma konuları olabilir.

Dijital medya ve aktivist halkla ilişkiler bağını kuran makaleler özelinde, aktivist halkla ilişkilerin hedef kurum üzerinde ne gibi etkilere yol açtığına bakıldığında genel olarak hedef kurum üzerinde baskı uyguladığı görülmüştür. Dijital mecralarda gerçekleştirilen aktivist halkla ilişkiler etkinlikleri kurumsal itibarın azalmasına, satışların ve hisselerin düşmesine, kurumların uyguladığı politikalarda değişime gitmesine sebep olmaktadır. İncelenen makalelerde aktivist halkla ilişkiler etkinlikleri karşısında hedef kurumun genel eğilimlerinin; ortaya çıkan soruna cevap vermemek, aktivist gruplarla uzlaşmaya gitmemek şeklinde olduğu görülmektedir. Bu genel eğilim sebebiyle hedef kurumların kurumsal krizle karşı karşıya kaldığı, bununla birlikte internet çağında bu krizlerin başladığı yerde kalmayıp küresel krizlere dönüştüğü görülmektedir. Bu sebeple bu çalışmada, kurumların bir sorunla karşılaştıklarında, sorun krize dönüşmeden aktivist gruplarla uzlaşmaya gitmesi önerilmektedir. Hatta bu sorun ortaya çıkmadan proaktif stratejilerle ve sürdürülebilirlik çalışmalarıyla, toplumsal ve çevresel sorunlar hakkında aktivist halkla ilişkiler faaliyetlerine başvurmaları gerekmektedir. Bu bağlamda, kâr amacı güden 
kuruluşlar ve halkla ilişkiler uygulayıcıları, günümüzde yalnızca kâr odaklı olmanın yeterli olmadığını ve kazan-kazan durumunun gerekli olduğunu anlamalı ve toplumsal vicdan ve etik anlayışı ile faaliyetlerini yürütmelidir.

Incelenen makalelere genel olarak bakıldığında dijital medyanın halkla ilişkiler alanında yeni araştırma konuları ve mecraların ortaya çıkmasını sağladığı görülmektedir. Dijital medyanın aktivist halkla ilişkilere nasıl katkı sağladığı ve dijital mecralarda gerçekleştirilen aktivist halkla ilişkiler konuları bunlardan biridir. Özellikle aktivist grupların ve kâr amacı gütmeyen kuruluşların dijital medyayı kullanmaları halkla ilişkiler uygulamalarını geliştirmek için bir fırsat sunmaktadır. Geleneksel medyada kendilerine ekonomik ve ideolojik sebepler nedeniyle yer bulamayan bu gruplar ve etkinlikleri dijital medya aracılığıla önemli bir görünürlük kazanabilme şansına sahiptir. Dijital medya bu gruplara kendilerini ifade edebilecekleri demokratik bir ortam sunmaktadır. Bununla birlikte, aktivist halkla ilişkiler etkinliklerinde hedef durumunda olan kurumlara daha açık ve simetrik bir iletişim gerçekleştirme, toplumsal ve çevresel sorumlulukları yerine getirme konusunda baskı oluşturulmaktadır. Proaktif bir sorun yönetimiyle hem şirketlerin hem de kamuların yararına sonuçlar elde edilmesi muhtemeldir. Bu sebeple yeni bir araştırma konusu olan dijital medya aracılığıyla gerçekleştirilen aktivist halkla ilişkiler konusunda daha çok çalışmanın gerçekleştirilmesi bu alandaki literatürü geliştirmenin yanında kurumlar ve kamu arasındaki iletişimin karşılıklı fayda sağlayacak şekilde gerçekleşmesini sağlayacaktır.

Sonuç olarak, bu çalışmada yeni bir araştırma konusu olarak dijital medyanın aktivist halkla ilişkiler üzerindeki etkisi, halkla ilişkiler literatüründe önemli yere sahip dergiler arasında yer alan ve alandaki yeni eğilimlerin, yeni konuların yer aldığı Public Relations Review, Public Relations Inquiry, Journal of Public Relations Research dergileri üzerinden uluslararası literatür incelenmiştir. Daha önce bu konuda bir inceleme yapılmamış olması ve ülkemizde yeni bir çalışma alanı olması sebebiyle gelecek çalışmalara örnek olması açısından önem atfetmektedir. Dijitalleşme, halkla ilişkiler alanına yeni çalışma alanlarıyla birlikte birçok kolaylığı da getirmiştir. Dijital medya iletişimi dönüştürmekle kalmayıp hem kurumların hem de kamuların davranışlarını da dönüştürmüştür. Bu bağlamda dijital medyanın gelişimi halkla ilişkiler alanında yeni araştırma konularının ortaya çıkmasını sağlamıştır. Bu durum da halkla ilişkiler literatürünü geliştirmekte ve zenginleştirmektedir. Bu çalışmanın da araştırma konusu olan dijital medya ve aktivist halkla ilişkiler çalışmaları hem teori hem de uygulama açısından alana katkı sağlayacaktır. Bu sebeple bu konuda gelecek çalışmaların aynı dergiler üzerinden tekrarlanması veya farklı uluslararası dergiler üzerinden incelemenin gerçekleştirilmesi, bu konudaki uluslararası literatürdeki genel eğilimleri ortaya koyarak ülkemizde halkla ilişkiler alanında yapılacak çalışmalara büyük bir zenginlik sağlayacaktır.

\section{KAYNAKÇA}

Aktaş, M. (2021). Stratejik iletişim araştırmalarında yeni yönelimler: Uluslararası literatürdeki tartışmalar üzerine bir analiz. Selçuk Iletişim Dergisi, 14(1), 363-382.

Allagui, I. (2017). Towards organisational activism in the UAE: A case study approach. Public Relations Review, 43(1), 258-266. 


\section{MEDIIAJ}

Botan, C. H., \& Taylor, M. (2004). Public relations: State of the field. Journal of Communication, 54(4), 645-661.

Chen, Z. (2020). Who becomes an online activist and why: Understanding the publics in politicized consumer activism. Public Relations Review, 46(1), 101854.

Ciszek, E. L. (2015). Bridging the gap: Mapping the relationship between activism and public relations. Public Relations Review, 41(4), 447-455.

Ciszek, E. L. (2016). Digital activism: How social media and dissensus inform theory and practice. Public Relations Review, 42(2), 314-321.

Coombs, W. T., \& Holladay, S. J. (2014). It's not just pr: Public relations in society. Wiley Blackwell.

Demetrious, K. (2013). Public relations, activism and social change: Speaking up. Routledge.

Demetrious, K. (2019). 'Energy wars': Global pr and public debate in the 21st century. Public Relations Inquiry, 8(1), 7-22.

Görpe, S. (2013). Bir meslek olarak halkla ilişkilerin değerlendirilmesi ve halkla ilişkilerde profesyonellik anlayışı: Meslek örgütlerinin mesleğe ve profesyonelliğe katkısı. M. Yamanoğlu Aktaş \& B. P. Özdemir (Ed.). Halkla ilişkilerin kazancı: Geçmiş eğilimler, yeni yönelimler (s. 283334). De Ki.

Grunig, J. E., \& Grunig, L. A. (2005). The role of public relations in transitional societies. R. Lawniczak (Ed.), Introducing market economy institutions and instruments: The role of public relations in transitional economies (s. 3-25). Wydawnictwo Piar.pl.

Grunig, L. (2005). Eylemcilik: Örgütlerin etkinliğini nasıl sınırlıyor ve mükemmel halkla iliş̧iler departmanları nasıl karşılık vermeli. J. E. Grunig (Ed.), Halkla ilişkiler ve iletişim yönetiminde mükemmellik (s. 527-556). Rota.

Harlow, R. F. (1976). Building a public relations definition. Public Relations Review, 2(4), $34-42$.

Holtzhausen, D. R. (2000). Postmodern values in public relations. Journal of Public Relations Research, 12(1), 93-114.

Holtzhausen, D. R., \& Voto, R. (2002). Resistance from the margins: The postmodern public relations practitioner as organizational activist. Journal of Public Relations Research, 14(1), 57-84.

Honda, L. P. (2016). Motivation for activists' participation in the 'it gets better project'. Public Relations Inquiry, 5(3), 253-276. 


\section{MEDIIAJ}

Kıyan, Z. (2019). Iletişim teknolojileri ve toplumsal hareketler: Sistematik bir literatür incelemesi. Gaziantep University Journal of Social Sciences18(2), 759-779.

Krippendorff, K. (1980). Content analysis an introduction to its Methodology. Sage.

Reber, H. B., \& Kim, J. K. (2006). How activist groups use websites in media relations: Evaluating online press rooms. Journal of Public Relations Research, 18(4), 313-333.

SCImago. (2021, Nisan). Scimago Journal \& Country Rank. https://www.scimagojr.com/journalsearch.php?q=public+relations

Seo, H., Kim, J. Y., \& Yang, S.-U. (2009). Global activism and new media: A study of transnational ngo's online public relations. Public Relations Review, 35(2), 123-126.

Smith, M. F. (2013). Activism. R. L. Heath (Ed.), Encyclopedia of public relations (s. 6-8). Sage Publications.

Sommerfeldt, E. J. (2013). Online power resource management: Activist resource mobilization, communication strategy, and organizational structure. Journal of Public Relations Research, 25(4), 347-367.

Sommerfeldt, E. J., \& Yang, A. (2017). Relationship networks as strategic issues management: An issue-stage framework of social movement organization network strategies. Public Relations Review, 43(4), 829-839.

Sommerfeldt, E. J., Kent, M. L., \& Taylor, M. (2012). Activist practitioner perspectives of website public relations: Why aren't activist websites fulfilling the diologic promise? Public Relations Review, 38(2), 303-312.

Stokes, A. Q., \& Atkins-Sayre, W. (2018). PETA, rherotical fracture, and the power of digital activism. Public Relations Inquiry, 7(2), 149-170.

Tapscott, D., \& Ticoll, D. (2003). The naked corporations: How the age of transparency will revolutionize business. Free Press.

Uysal, N., \& Yang, A. (2013). The power of activist networks in the mass selfcommunication era: A triangulation study of the impact of wikileaks on the stock value of Bank of America. Public Relations Review, 39(5), 459-469.

Vardeman, J., \& Sebesta, A. (2020). The problem of intersectionality as an approach to digital activism: The women's march on washington's attempt to unite all women. Journal of Public Relations Research, 32(1-2), 7-29.

Veil, S. R., Reno, J., Freihaut, R., \& Oldham, J. (2015). Online activists vs. Kraft Foods: A case of social media hijacking. Public Relations Review, 41(1), 103-108.

Vercic, D., Vercic, A. T., \& Sriramesh, K. (2015). Looking for digital in public relations. Public 


\section{MEDIIAJ}

Relations Review, 41(2), 142-152.

Victor, L. (2008). Systematic reviewing. Social Research Update, 54(Summer), 1-4.

Wakefield, R. I. (2007). Theory of international public relations, the internet, and activism: A personal reflection. Journal of Public Relations Research, 20(1), 138-157.

Williams, R. (2008). Eylemsellik ve halkla ilişkiler. S. Yıldırım Becerikli (Ed.), Ve halkla ilişkiler (s. 437-448). Karınca.

Xiong, Y., Cho, M. \& Boatwright, B. (2019). Hashtag activism and message frames among social movement organizations: Semantic network analysis and thematic analysis of twitter during the \#metoo movement. Public Relations Review, 45(1), 10-23.

Ek 1. Literatür Taraması Genel Veriler

\begin{tabular}{|c|c|c|c|c|c|c|c|}
\hline No & Dergi & Konu & $\begin{array}{l}\text { Aktivist } \\
\text { Halkla } \\
\text { ilişkiler } \\
\text { Uygulayıcısı }\end{array}$ & $\begin{array}{l}\text { Aktivist Halkla } \\
\text { İlişkilerin } \\
\text { Uyglandığı } \\
\text { Dijital Mecra }\end{array}$ & $\begin{array}{l}\text { Kullanılan } \\
\text { Yöntem }\end{array}$ & Ulaşılan Temel Sonuç & Atıf \\
\hline M1 & $\begin{array}{l}\text { Public } \\
\text { Relations } \\
\text { Review }\end{array}$ & $\begin{array}{l}\text { STK'ların aktivist } \\
\text { halkla ilişkiler } \\
\text { çalışalarında } \\
\text { yeni medyayı } \\
\text { nasıl } \\
\text { kullandıkları. }\end{array}$ & $\begin{array}{l}\text { Sivil Toplum } \\
\text { Kuruluşu }\end{array}$ & $\begin{array}{l}\text { Website, } \\
\text { Bloglar, } \\
\text { Videocast, } \\
\text { Podcast, } \\
\text { Wikiler, } \\
\text { Facebook, } \\
\text { Twitter }\end{array}$ & $\begin{array}{l}\text { Anket } \\
\text { (75 } \\
\text { Uluslararası } \\
\text { STK ile) }\end{array}$ & $\begin{array}{l}\text { STK'lar için yeni } \\
\text { medyanın önemli iki } \\
\text { işlevi bulunur: } \\
\text { Kuruluşun imajına olan } \\
\text { katkısı ve kaynak } \\
\text { yaratmayı } \\
\text { desteklemesi. }\end{array}$ & $\begin{array}{l}\text { Seo vd., } \\
2009\end{array}$ \\
\hline M2 & $\begin{array}{l}\text { Public } \\
\text { Relations } \\
\text { Review }\end{array}$ & $\begin{array}{l}\text { Aktivist } \\
\text { uygulayıcılarının } \\
\text { website } \\
\text { üzerinden } \\
\text { gerçekleştirilen } \\
\text { halkla ilişkiler } \\
\text { üzerine } \\
\text { görüşleri ve } \\
\text { websitelerin } \\
\text { diyalojik } \\
\text { prensibe göre } \\
\text { incelenmesi. }\end{array}$ & $\begin{array}{l}\text { Aktivist } \\
\text { Gruplar }\end{array}$ & Website & $\begin{array}{l}\text { İçerik Analizi } \\
\text { (Aktivist } \\
\text { websiteleri } \\
\text { üzerine), } \\
\text { Derinlemesine } \\
\text { Görüşme (13 } \\
\text { aktivist halkla } \\
\text { ilişkiler } \\
\text { uzmanı ile) }\end{array}$ & $\begin{array}{l}\text { Görüşme sonucu } 3 \\
\text { konu ortaya çıkmıştır: } \\
\text { Website belirli bir } \\
\text { soruna yönelik } \\
\text { etkinliklerde en etkili } \\
\text { araçtır,yüksek katılımlı } \\
\text { kitlelere hitap eder ve } \\
\text { geleneksel halkla } \\
\text { ilişkiler çalışmalarıyla } \\
\text { desteklenmelidir. }\end{array}$ & $\begin{array}{l}\text { Sommerfeld } \\
\text { t vd., } 2012\end{array}$ \\
\hline M3 & $\begin{array}{l}\text { Public } \\
\text { Relations } \\
\text { Review }\end{array}$ & $\begin{array}{l}\text { Aktivist ağların } \\
\text { gücü- } \\
\text { WikiLeaks'in } \\
\text { Bank of America } \\
\text { hisse değerleri } \\
\text { üzerine etkisi. }\end{array}$ & $\begin{array}{l}\text { Aktivist } \\
\text { Gruplar }\end{array}$ & WikiLeaks & $\begin{array}{l}\text { Sosyal Ağ } \\
\text { Analizi } \\
\text { (WikiLeaks), } \\
\text { Olay Çalışması } \\
\text { (event study) }\end{array}$ & $\begin{array}{l}\text { WikiLeaks aktivist ağın } \\
\text { BOA hisse değerini } \\
\text { nasıl etkilediğini ortaya } \\
\text { koymaktadır. }\end{array}$ & $\begin{array}{l}\text { Uysal\&Yang, } \\
2013\end{array}$ \\
\hline
\end{tabular}




\section{MEDIAJ}

\begin{tabular}{|c|c|c|c|c|c|c|c|}
\hline M4 & $\begin{array}{l}\text { Public } \\
\text { Relations } \\
\text { Review }\end{array}$ & $\begin{array}{l}\text { Çevrimiçi } \\
\text { aktivistlerin kar } \\
\text { amacı güden bir } \\
\text { şirket üzerine } \\
\text { gerçekleştirdikle } \\
\text { ri sosyal medya } \\
\text { saldırısı. }\end{array}$ & $\begin{array}{l}\text { Aktivist } \\
\text { Gruplar }\end{array}$ & Facebook & $\begin{array}{l}\text { Vaka Çalışması } \\
\text { (Kraft Foods } \\
\text { şirketine } \\
\text { yönelik } \\
\text { gerçekleştirile } \\
\text { n aktivist } \\
\text { çalışmalar) }\end{array}$ & $\begin{array}{l}\text { Sosyal medya } \\
\text { saldırısının ve pasif } \\
\text { aktivizmin nasıl küresel } \\
\text { bir etki yaratabileceği, } \\
\text { kurumlar için proaktif } \\
\text { sorun yönetiminin ve } \\
\text { aktivistler hakkında } \\
\text { daha çok bilgi } \\
\text { toplamanın önemi } \\
\text { ortaya konmuştur. }\end{array}$ & $\begin{array}{l}\text { Veil vd., } \\
2015\end{array}$ \\
\hline M5 & $\begin{array}{l}\text { Public } \\
\text { Relations } \\
\text { Review }\end{array}$ & $\begin{array}{l}\text { Postmodern } \\
\text { anlaşmazlık } \\
\text { kavramı } \\
\text { üzerinden } \\
\text { aktivist } \\
\text { grupların } \\
\text { şirketler } \\
\text { aleyhine } \\
\text { gerçeklştirdikler } \\
\text { i aktivist halkla } \\
\text { ilişkiler } \\
\text { etkinlikleri. }\end{array}$ & $\begin{array}{l}\text { Aktivist } \\
\text { Gruplar }\end{array}$ & Facebook & $\begin{array}{l}\text { Tematik Analiz } \\
\text { (Facebook } \\
\text { sayfası } \\
\text { kullanıcı } \\
\text { yorumları) }\end{array}$ & $\begin{array}{l}\text { Şirket ve kullanıcıları } \\
\text { arasında bir görüş } \\
\text { ayrılığı olması sonucu, } \\
\text { kullanıcıların sosyal } \\
\text { medyayı kullanarak } \\
\text { şirketi güçsüz kılacak } \\
\text { aktivist hareketlere } \\
\text { başvurabildikleri ve } \\
\text { bunda sosyal medyanın } \\
\text { gücünün ne denli } \\
\text { büyük olduğu ortaya } \\
\text { konmuştur. }\end{array}$ & Cizsek, 2016 \\
\hline M6 & $\begin{array}{l}\text { Public } \\
\text { Relations } \\
\text { Review }\end{array}$ & $\begin{array}{l}\text { Kar amacı } \\
\text { güden } \\
\text { kuruluşların } \\
\text { uyguladığı } \\
\text { aktivizme } \\
\text { Birleşik Arap } \\
\text { Emirlikleri'nden } \\
\text { örnekler. }\end{array}$ & $\begin{array}{l}\text { Kar amacı } \\
\text { güden } \\
\text { kuruluşlar }\end{array}$ & $\begin{array}{l}\text { Youtube, } \\
\text { Facebook, } \\
\text { Twitter, } \\
\text { Bloglar }\end{array}$ & $\begin{array}{l}\text { Vaka Çalışması } \\
\text { (Birleşik } \\
\text { ArapEmirlikler } \\
\text { i'nde } \\
\text { kurumsal } \\
\text { aktivizm) }\end{array}$ & $\begin{array}{l}\text { Sosyal medyanın } \\
\text { etkisiyle şirketlerin de } \\
\text { sosyal aktörler olarak } \\
\text { hareket edebildikleri ve } \\
\text { toplumdaki } \\
\text { eşitsizliklere karşı } \\
\text { aktivizmi } \\
\text { gerçekleştirebildikleri } \\
\text { ortaya konmuştur. }\end{array}$ & Allagui,2017 \\
\hline M7 & $\begin{array}{l}\text { Public } \\
\text { Relations } \\
\text { Review }\end{array}$ & $\begin{array}{l}\text { Toplumsal } \\
\text { hareket } \\
\text { örgütlerinin } \\
\text { Hashtag } \\
\text { aktvizmi } \\
\text { (Twitter } \\
\text { üzerindeki } \\
\text { \#meToo } \\
\text { hareketi) }\end{array}$ & $\begin{array}{l}\text { Toplumsal } \\
\text { Hareket } \\
\text { Örgütleri }\end{array}$ & Twitter & $\begin{array}{l}\text { Semantik Ağ } \\
\text { Analizi, } \\
\text { Tematik Analiz } \\
\text { (\#meToo } \\
\text { hashtagi ile } \\
\text { yapılan } \\
\text { paylaşımlar) }\end{array}$ & $\begin{array}{l}\text { Aktivist kampanyada } \\
\text { hashtag aktivizminin } \\
\text { önemli bir rol oynadığı; } \\
\text { yerel başlayan } \\
\text { kampanyanın küresel } \\
\text { bir topluluğa ve } \\
\text { farkındalığa ulaştığı } \\
\text { görülmüştür. }\end{array}$ & $\begin{array}{l}\text { Xiong vd., } \\
2019\end{array}$ \\
\hline
\end{tabular}


MEEDIAJ

\begin{tabular}{|c|c|c|c|c|c|c|c|}
\hline M8 & $\begin{array}{l}\text { Public } \\
\text { Relations } \\
\text { Review }\end{array}$ & $\begin{array}{l}\text { Kimler, ne için } \\
\text { çevrimiçi } \\
\text { aktivist olur? } \\
\text { Politikleştirilmiş } \\
\text { tüketici } \\
\text { aktivizmi. }\end{array}$ & $\begin{array}{l}\text { Aktivist } \\
\text { Gruplar }\end{array}$ & Weibo & $\begin{array}{l}\text { Vaka Çalışması } \\
\text { (Lancome), } \\
\text { Çevrimiçi } \\
\text { Anket (450 } \\
\text { katılımcı ile) }\end{array}$ & $\begin{array}{l}\text { Aktivistler politik } \\
\text { nedenlerden dolayı da } \\
\text { kurumları boykot } \\
\text { edebilmektedir. } \\
\text { İncelenen vakalarda } \\
\text { kurumların politik } \\
\text { nedenlerle harekete } \\
\text { geçen aktivistlerle } \\
\text { diyalog kurmaya hazır } \\
\text { olmadığı görülmüşı̈r. }\end{array}$ & Chen, 2020 \\
\hline M9 & $\begin{array}{l}\text { Journal } \\
\text { of Public } \\
\text { Relations } \\
\text { Research }\end{array}$ & $\begin{array}{l}\text { Aktivist } \\
\text { grupların medya } \\
\text { ilişkilerinde } \\
\text { website } \\
\text { kullanımları. }\end{array}$ & $\begin{array}{l}\text { Aktivist } \\
\text { Gruplar }\end{array}$ & Website & $\begin{array}{l}\text { İçerik Analizi } \\
\text { (74 aktivist } \\
\text { kuruluşun } \\
\text { websitesi) }\end{array}$ & $\begin{array}{l}\text { Analiz edilen kuruluş } \\
\text { websitelerinin yalnızca } \\
\text { üçte birinde basın } \\
\text { odası bulunduğu ve } \\
\text { websitelerin } \\
\text { gazeteciler için yeterli } \\
\text { diyalojik özellikler } \\
\text { içermediği ortaya } \\
\text { çıkmıştır. }\end{array}$ & $\begin{array}{l}\text { Reber\&Kim, } \\
2006\end{array}$ \\
\hline M10 & $\begin{array}{l}\text { Journal } \\
\text { of Public } \\
\text { Relations } \\
\text { Research }\end{array}$ & $\begin{array}{l}\text { Uluslararası } \\
\text { halkla ilişkiler } \\
\text { teorisi, internet } \\
\text { ve aktivizm } \\
\text { üzerine bir } \\
\text { değerlendirme }\end{array}$ & $\begin{array}{l}\text { Aktivist } \\
\text { Gruplar }\end{array}$ & $\begin{array}{l}\text { Genel Kapsam } \\
\text { Olarak } \\
\text { Internet }\end{array}$ & $\begin{array}{l}\text { Literatür } \\
\text { Çalışması }\end{array}$ & $\begin{array}{l}\text { İnternetin kullanımının } \\
\text { artmasıyla aktivizmin } \\
\text { uluslararası halkla } \\
\text { ilişkiler etkinlikleri } \\
\text { üzerindeki etkisi } \\
\text { artmıştır. }\end{array}$ & $\begin{array}{l}\text { Wakefield, } \\
2007\end{array}$ \\
\hline M11 & $\begin{array}{l}\text { Journal } \\
\text { of Public } \\
\text { Relations } \\
\text { Research }\end{array}$ & $\begin{array}{l}\text { Aktivistlerin } \\
\text { websitelerinde } \\
\text { kaynak } \\
\text { mobilizasyonun } \\
\text { un nasıl } \\
\text { kullanıldığı ve } \\
\text { bunun aktivist } \\
\text { stratejiler } \\
\text { üzerindeki } \\
\text { belirleyiciliği. }\end{array}$ & $\begin{array}{l}\text { Aktivist } \\
\text { Gruplar }\end{array}$ & Website & $\begin{array}{l}\text { İçerik Analizi } \\
\text { (300 aktivist } \\
\text { kuruluşun } \\
\text { websitesi) }\end{array}$ & $\begin{array}{l}\text { Sorun yönetimi için } \\
\text { aktivist websiteleri } \\
\text { üzerinde harekete } \\
\text { geçirilen kaynaklar ile } \\
\text { aktivist stratejiler, } \\
\text { sorun hedefleri ve } \\
\text { organizasyon yapısının } \\
\text { birbiriyle ilişki halinde } \\
\text { olduğu ortaya } \\
\text { konmuştur. }\end{array}$ & $\begin{array}{l}\text { Sommerfeld } \\
\text { t,2013 }\end{array}$ \\
\hline M12 & $\begin{array}{l}\text { Journal } \\
\text { of Public } \\
\text { Relations } \\
\text { Research }\end{array}$ & $\begin{array}{l}\text { Dijital aktivizm } \\
\text { örneği olarak, } \\
\text { kadınlara karşı } \\
\text { yapılan } \\
\text { ayrımcılığa karşı } \\
\text { Washington } \\
\text { Kadınlar } \\
\text { Yürüyüşü. }\end{array}$ & $\begin{array}{l}\text { Aktivist } \\
\text { Gruplar }\end{array}$ & $\begin{array}{l}\text { Website } \\
\text { (womensMarc } \\
\text { h.com), } \\
\text { Twitter, } \\
\text { Facebook, } \\
\text { İnstagram }\end{array}$ & $\begin{array}{l}\text { Tematik Analiz } \\
\text { (womensMarc } \\
\text { h.com ve } \\
\text { Twitter, } \\
\text { Facebook, } \\
\text { Instagram } \\
\text { hesapları) }\end{array}$ & $\begin{array}{l}\text { Kampanya bir gecede } \\
\text { büyük bir küresel } \\
\text { erişim gerçekleştirmiş } \\
\text { bu da sosyal medyanın } \\
\text { aktivizm için önemini } \\
\text { ortaya koymuştur. } \\
\text { Sosyal medyadaki } \\
\text { paylaşımlarda } \\
\text { Washington Kadınlar } \\
\text { Yürüyüşü kamuları için } \\
\text { politik bir değişim talep }\end{array}$ & $\begin{array}{l}\text { Vardeman\& } \\
\text { Sebesta, } \\
2020\end{array}$ \\
\hline
\end{tabular}




\section{ME[DIAJ}

\begin{tabular}{|c|c|c|c|c|c|c|c|}
\hline & & & & & & $\begin{array}{l}\text { eden mesajların yoğun } \\
\text { olarak yer aldığı } \\
\text { görülmüştür. }\end{array}$ & \\
\hline M13 & $\begin{array}{l}\text { Public } \\
\text { Relations } \\
\text { Inquiry }\end{array}$ & $\begin{array}{l}\text { LGTBQ } \\
\text { gençlerinin } \\
\text { artan intihar } \\
\text { oranlarına tepki } \\
\text { için } \\
\text { gerçekleştirilen } \\
\text { Youtube tabanlı } \\
\text { 'It Gets Better } \\
\text { Project' adlı } \\
\text { kampanyaya } \\
\text { aktivislerin } \\
\text { katılma } \\
\text { motivasyonları. }\end{array}$ & $\begin{array}{l}\text { Aktivist } \\
\text { Gruplar }\end{array}$ & $\begin{array}{l}\text { Website } \\
\text { (itgetsbetter.o } \\
\text { rg), Youtube, } \\
\text { Resmi Blog, } \\
\text { Facebook, } \\
\text { Google Plus, } \\
\text { Tumblr, } \\
\text { Twitter }\end{array}$ & $\begin{array}{l}\text { Çevrimiçi ve } \\
\text { Yarı } \\
\text { Yapılandırılmış } \\
\text { Derinlemesine } \\
\text { Görüşme (20 } \\
\text { IGBP } \\
\text { katııımcısı ile) }\end{array}$ & $\begin{array}{l}\text { Katılımcıların } \\
\text { motivasyonlarının çok } \\
\text { yönlü olduğu ve üç ana } \\
\text { motivasyon nedeninin } \\
\text { sorun hakkında bir } \\
\text { dayanışma } \\
\text { gerçekleştirmek, } \\
\text { sorunun düzeltilmesi } \\
\text { ve bu dezavantajlı } \\
\text { grupların medyada } \\
\text { temsilinin sağlanması } \\
\text { olduğu sonucuna } \\
\text { varılmıştır. }\end{array}$ & Honda, 2016 \\
\hline M14 & $\begin{array}{l}\text { Public } \\
\text { Relations } \\
\text { Inquiry }\end{array}$ & $\begin{array}{l}\text { Aktivist bir } \\
\text { toplumsal } \\
\text { hareket örgütü } \\
\text { olan PETA'nın } \\
\text { SeaWorld } \\
\text { şrketini } \\
\text { protesto etmek } \\
\text { için dijital } \\
\text { aktivizmi } \\
\text { kullanması. }\end{array}$ & $\begin{array}{l}\text { Toplumsal } \\
\text { Hareket } \\
\text { Örgütü }\end{array}$ & Website & $\begin{array}{l}\text { Retorik Analiz } \\
\text { (PETA/SeaWor } \\
\text { Id tartışması) }\end{array}$ & $\begin{array}{l}\text { PETA'nın } \\
\text { gerçekleştirdiği dijital } \\
\text { aktivizm sonucu } \\
\text { şirketin hisseleri yüzde } \\
40 \text { düşmüş karı yüzde } \\
84 \text { azalmış ve şirkette } \\
\text { kurumsal politika } \\
\text { değişikliğine neden } \\
\text { olmuştur. Bu durum } \\
\text { dijital aktivizmin } \\
\text { toplumsal konulardaki } \\
\text { değişimi } \\
\text { gerçekleştirmedeki } \\
\text { önemi. }\end{array}$ & $\begin{array}{l}\text { Stokes\&Atki } \\
\text { ns-Sayre, } \\
2018\end{array}$ \\
\hline M15 & $\begin{array}{l}\text { Public } \\
\text { Relations } \\
\text { Inquiry }\end{array}$ & $\begin{array}{l}\text { Küresel bir } \\
\text { tartışma konusu } \\
\text { olan enerji } \\
\text { yoksulluğu } \\
\text { hakkında bir } \\
\text { enerji şirketi } \\
\text { tarafından } \\
\text { gerçekleştirilen } \\
\text { halkla ilişkiler } \\
\text { kampanyası. }\end{array}$ & $\begin{array}{l}\text { Kar Amacı } \\
\text { Güden } \\
\text { Kuruluş }\end{array}$ & Twitter & $\begin{array}{l}\text { Alımlama } \\
\text { çalışması } \\
\text { (kampanya), } \\
\text { İçerik Analizi } \\
\text { (Twitter) }\end{array}$ & $\begin{array}{l}\text { Kampanya ile enerji } \\
\text { yoksulluğu konsunda } \\
\text { küresel bir farkındalık } \\
\text { yaratılmıştır. Elde } \\
\text { edilen bulgular } 21 . \\
\text { yüzyılda halkla ilişkiler } \\
\text { ve aktivizmin; } \\
\text { toplumsal değişimi, } \\
\text { kamu tartışmalarına } \\
\text { katııımı anlamada } \\
\text { önemli olduğunu } \\
\text { ortaya koymuştur. }\end{array}$ & $\begin{array}{l}\text { Demetrious, } \\
2019\end{array}$ \\
\hline
\end{tabular}

